\title{
A Great Catch for Investigating Inborn Errors of Metabolism-Insights Obtained from Zebrafish
}

\author{
Maximilian Breuer ${ }^{1, *(1)}$ and Shunmoogum A. Patten ${ }^{1,2}$ \\ 1 INRS-Centre Armand-Frappier Santé et Biotechnologie, 531 Boulevard des Prairies, Laval, QC H7V 1B7, \\ Canada; kessen.patten@iaf.inrs.ca \\ 2 Centre d'Excellence en Recherche sur les Maladies Orphelines-Fondation Courtois (CERMO-FC), \\ Université du Québec à Montréal (UQAM), Montréal, QC H3C3P8, Canada \\ * Correspondence: maximilian.breuer@iaf.inrs.ca; Tel.: +1-450-687-5010 (ext. 8864)
}

Received: 10 August 2020; Accepted: 19 September 2020; Published: 22 September 2020

\begin{abstract}
Inborn errors of metabolism cause abnormal synthesis, recycling, or breakdown of amino acids, neurotransmitters, and other various metabolites. This aberrant homeostasis commonly causes the accumulation of toxic compounds or depletion of vital metabolites, which has detrimental consequences for the patients. Efficient and rapid intervention is often key to survival. Therefore, it requires useful animal models to understand the pathomechanisms and identify promising therapeutic drug targets. Zebrafish are an effective tool to investigate developmental mechanisms and understanding the pathophysiology of disorders. In the past decades, zebrafish have proven their efficiency for studying genetic disorders owing to the high degree of conservation between human and zebrafish genes. Subsequently, several rare inherited metabolic disorders have been successfully investigated in zebrafish revealing underlying mechanisms and identifying novel therapeutic targets, including methylmalonic acidemia, Gaucher's disease, maple urine disorder, hyperammonemia, TRAPPC11-CDGs, and others. This review summarizes the recent impact zebrafish have made in the field of inborn errors of metabolism.
\end{abstract}

Keywords: zebrafish; inborn errors of metabolism; disease model; genetic disorders

\section{Introduction}

\subsection{Rare Inherited Metabolic Disorders}

Monogenic congenital disorders, affecting a metabolic pathway, commonly resulting in a deficiency or accumulation of a specific metabolite, have been coined "inborn errors of metabolism" (IEM) [1]. This large collection of rare genetic diseases includes over 700 genetic diseases. Even though the occurrence of a specific IEM is rare to extremely rare, collectively they have an incidence rate of up to 1 in 800-5000 newborn [2-4]. Additionally, the occurrence and frequencies differ among regions, ethnicities, and populations [5-10]. With the advent of fast and efficient high-throughput sequencing, the number of genes associated with IEM is continuously increasing. Importantly, the use of whole-exome sequencing in the clinical setting has enhanced the diagnosis efficiency of IEM during prenatal and newborn screening. Furthermore, it has simplified the identification of mutations and genes involved in previously unresolved cases of metabolic disorders, therefore, enabling us to investigate the genes of interest, as well as genotype-phenotype correlations [11-13]. IEM account for a large factor of morbidity and mortality among children and who often have no available treatment or/are diagnosed with IEM at a too late stage to be treated. Some IEM have also been linked to sudden infant death [14]. Detection of IEM within the first 48 hours is thus vital to prevent any physical and/or mental retardation, yet proper diagnosis and testing of IEM are still challenging $[15,16]$. One effective 
way for clinicians to detect and combat IEM is via newborn screening, which analyzes key metabolites of newborns to identify biomarkers as early as possible and initiate treatment [17]. Treatment, if available, includes dietary control/restrictions and/or compound supplementation [18,19]. Recently additional treatment options for IEM have become available, including enzyme replacement therapy. Even though IEM are often considered as pediatric diseases, they can manifest later in life [20,21]. To advance our knowledge in the understanding of the underlying mechanisms of IEM, as well as to identify therapeutic targets, an efficient model, that can be designed successfully for the various genes and pathways, is needed. Furthermore, to improve the translatability of whole exome/genome sequencing, the decisive advantages of the models must be determined along with careful interpretation of data to accurately correlate results [22].

\subsection{Animal Models of IEM}

Animal models are commonly used to model and understand the underlying mechanisms of human diseases. The most commonly used animal in IEM investigations is Mus musculus (mouse) in about two-thirds of all studies, followed by Rattus norvegicus (rat) (Figure 1B). However, genotype-driven mutant generation often creates null-alleles which in the case of IEM is often a downfall, as some enzymatic activity may be retained in patients [23]. Nonetheless, numerous other model organisms are of interest to study IEM, such as Saccharomyces cerevisiae (yeast) [24], Caenorhabditis elegans (worm) [25-27], Drosophila melanogaster (fruit fly) [26,28,29], Felis catus (cat), and Canis familiaris (dog) [30-32], as well as Danio rerio (zebrafish). Among these model organisms, zebrafish only represent up 1.5\% of IEM related Pubmed hits (Figure 1B). Nonetheless, zebrafish have become of special interest in the investigation of metabolism in development [33], given its numerous advantages. Of those IEM investigated in zebrafish, the majority of the studies are focused on carbohydrate metabolism, lipoprotein metabolism, and lysosomal storage disorders (Figure 1C), however, all categories of IEM have been studied. While this simple search may under- or overrepresent certain factors and models, it gives an insight into the recent selection of animal models used for IEM research.

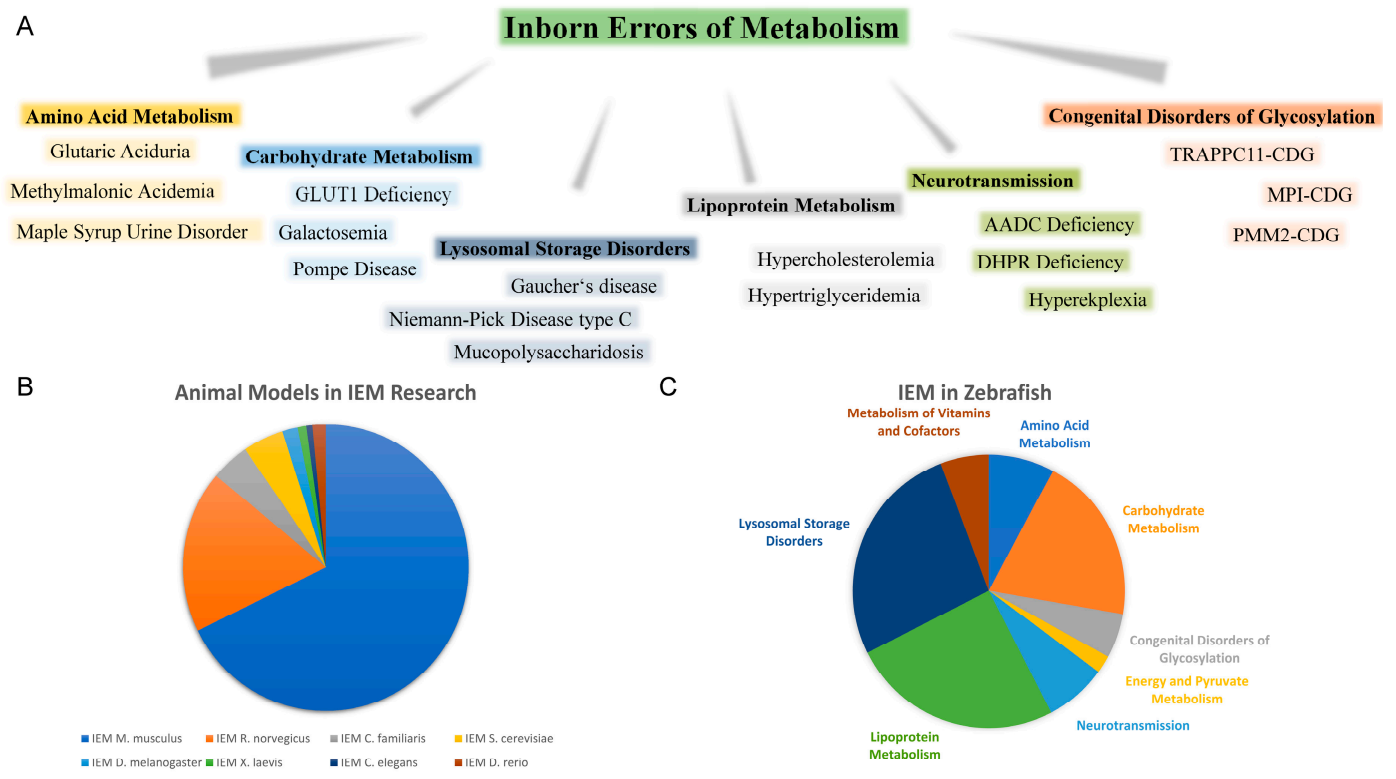

Figure 1. Overview of inborn errors of metabolism research. (A) Schematic presentation of major IEM Groups and selected disorders. (B) Diagram of animal models since the year 2000 used in IEM research based on Pubmed (https://www.ncbi.nlm.nih.gov/) hits (Search terms: "Inborn errors of metabolism + animal model") last accessed 22.06.2020 (C) Zebrafish publications in relation to IEM studied since the year 2000 based on Pubmed research hits (Search terms based on IEM disorder group and individual disorders) last accessed 07.08.2020. 


\subsection{Advantages of Zebrafish for Investigating Rare Inherited Metabolic Diseases}

In the last decades, zebrafish as a model organism has become an increasingly important tool in the understanding of rare inherited metabolic disorders and the development of novel therapeutic targets. The use of zebrafish has been rapidly increasing since the initial studies performed by George Streisinger [34]. In comparison to other animal models and cell culture, zebrafish have major advantages. Firstly, zebrafish have a high evolutionary conservation of genes and proteins compared to humans allowing analysis of genes associated with human disorders. Secondly, they develop rapidly enabling for first metabolic screens after $24 \mathrm{~h}$ post-fertilization (hpf). The simple genetic manipulation of larvae with approaches including CRISPR/Cas9, TALEN, morpholino targeting, and transgenic modification, also make this model organism a highly efficient tool for investigating inherited disorders such as IEM. Importantly, CRISPR/Cas9 mediated knockout efficiency has improved substantially in recent years with an ever-improving toolbox to generate zebrafish disease models [35-38].

Zebrafish development is incredibly well characterized regarding staging, neurological structures, cell migration/differentiation, and the zebrafish genome is also fully sequenced [39-44]. During teleost evolution, the zebrafish genome underwent a whole-genome duplication and therefore many human genes contain multiple zebrafish ortholog counterparts [45]. The resulting expression patterns of genes and orthologues may be more restrictive, allowing for investigation of protein function in development and tissue formation without resulting in embryonic lethality [46]. Furthermore, in some cases of IEM, a hypomorphic model may be more efficient to model disorders where some enzyme activity remains.

The use of zebrafish to model IEM requires highly conserved metabolic enzymes and pathways between humans and zebrafish. Zebrafish have been proven as highly effective in vivo models in this regard [47-49]. Recent research has also shown that metabolic profiling is fast and efficient for zebrafish larvae. Larvae can be profiled by mass spectrometry and HPLC to give a conclusive metabolic pattern of amines, amino acids, sugars, fatty acids, and citric acid cycle metabolites as early as 72 hpf $[50,51]$. Concurrent with the development of key metabolic organs, such as the liver, a stable profile could be determined during larval stages to investigate the metabolic role in tissue development [51]. Additionally, as many IEM results in severe neural and neurodegenerative symptoms, zebrafish are effective in modeling behavioral and neurodevelopmental diseases and their characteristics [52] (Figure 2).

Another major advantage of zebrafish is that it is amenable to high throughput drug screening. There are increasing reports of drug screen assays and small molecule testing in zebrafish disease models and/or on behavioral neurodevelopmental aspects [53-57]. Interestingly, several therapeutics identified in zebrafish have started to be translated into human clinical trials [56]. Recently zebrafish have also become of great interest in clinical studies due to the development of personalized avatars and therewith developing personalized treatment approaches [58,59].

This review provides a comprehensive summary of the most recent advances in rare metabolic disorder studies using the zebrafish vertebrate model (summarized in Table 1). 


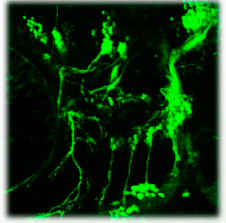

Neural development

Neurotransmitter

conservation

Effective cell tracing

Bone development

Rapid stainings

- Fast vertebral development

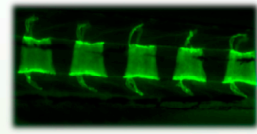

Craniofacial development

- Simple stainings

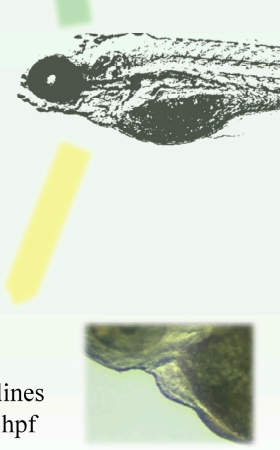

Organogenesis

Fast development

Defined staging

- Transparent larvae

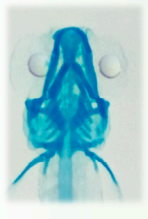

Heart development

- Use of transgenic lines

- Heartbeat after $24 \mathrm{hpf}$

- Traceable vasculature

Genetic and metabolic conservation

- Amino acid metabolism

- Energy metabolism

- Neurotransmitter metabolism

Figure 2. Advantages of zebrafish for metabolic studies. Overview of zebrafish advantages in regards to metabolic studies and metabolic conservation. The Figure highlights key developmental features that are important in investigating common characteristics of IEM, including heart deficits, craniofacial, spinal, as well as neural and organ abnormalities (Images presented: Neural development: lateral view of $72 \mathrm{hpf} \operatorname{tg}($ isl:GFP) transgenic line; Bone development: close up of vertebral calcein staining of 4-week old zebrafish larvae; Craniofacial development: Dorsal view of Alcian blue staining of $6 \mathrm{dpf}$ zebrafish larvae; Heart development: close up of $72 \mathrm{hpf}$ zebrafish heart, Genetic and Metabolic conservation: whole-mount in situ hybridization of glutamine synthetase in $5 \mathrm{dpf}$ larvae).

\section{Amino Acid and Peptide Metabolism}

One of the major groups of IEM results in the accumulation of organic acids due to a deficiency in the intermediary metabolism of amino acids, carbohydrates, and fatty acid oxidation [60,61]. Clinical features of organic acidurias, among hyperammonemia, include a wide range of symptoms such as developmental delay, mental retardation, hypoglycemia, seizures, and cardiac problems. Treatment involves a targeted restriction with additional supplementation of amino acid formulas [62]. Organic acidemias are grouped into maple syrup urine disease, methylmalonic acidemia, propionic acidemia, and isovaleric acidemia.

\subsection{Maple Syrup Urine Disease (MSUD)}

MSUD is a metabolic disorder resulting in branched-chain ketoaciduria, which is an accumulation of branched-chain amino acids (BCAA), such as valine, leucine, and isoleucine, and is caused by mutations in either of three genes, $B C K D H A, B C K D H B$ or $D B T$ [63]. MSUD causes developmental delay, behavioral abnormalities, and neurotoxicity. A $d b t^{-/-}$zebrafish mutant, termed "quetschkommode" has been shown to effectively reproduce the metabolic profile of MSUD, with increased BCAA, depletion of glutamate in the brain, as well as abnormal swimming behavior [64]. Such CRISPR/Cas9-based knockout models mimicking disease symptoms are incredibly useful for developing specific therapeutic strategies [57,65-67].

Recently, zebrafish were exposed to high levels of leucine and used to mimic MSUD to investigate psychological changes as observed in patients. This study showed an altered, cholinergic related behavior in zebrafish following exposure to high levels of leucine, suggesting another efficient model to study the effect of BCAA accumulation on behavior and neurochemistry in MSUD [68]. 


\subsection{Methylmalonic Acidemia (MMA)}

MMA is the most common organic acidurias with an incidence rate of 1:50,000 in the United States [61]. MMA is caused by either direct or indirect effect on the conversion of methylmalonyl-CoA to succinyl-CoA by methylmalonyl-CoA mutase (MMUT), which is vitamin B12 dependent [69-71]. A mouse knockout model for MMA showed neonatal lethality [72].

Mutations in the MMUT gene results in toxic accumulation of methylmalonic acid, propionic acid, and 2-methylcitric acid in the mitochondrial matrix. A zebrafish CRISPR/Cas9 knockout model for mmut exhibited altered mitochondrial morphology in both kidney and liver of larvae, along with increased mitochondrial oxidative stress $[73,74]$. The high mortality in larvae could be recovered with a low protein diet, which is also the current approach for the treatment of patients. This knockout model was used to test results from a drug-disease network-based computational modeling approach to identify possible target pathways [75]. The study showed that mitochondrial stress can be targeted separately from the methylmalonic acid accumulation, by using the known drug Mito-Q, which is commonly used in lysosomal storage disorders. Treatment did ameliorate both phenotypic severity and oxidative stress, indicating the importance of targeting pathways beyond the fundamental cellular mechanisms of the disease.

Directly related to MMA is cobalamin C deficiency, which results in ineffective processing and trafficking of vitamin B12. The lack of the cofactor for MMUT, subsequently perturbates its enzyme activity. A zebrafish knockout model of the causing gene mmachc is the first viable model organism, displaying typical disorder symptoms including MMA, retinopathy, and juvenile lethality [76]. The model proved to be effective for testing therapeutic approaches, with findings showing that small molecules already used for patients, such as hydroxocobalamin and methylcobalamin, recover the disease severity in this model.

\subsection{Multiple Acyl-CoA Dehydrogenase Deficiency/Glutaric Aciduria Type II}

Glutaric aciduria type II is considered as an IEM of fatty acid oxidation, but it is also directly implicated in BCAA metabolism. A zebrafish knockout mutant for the electron transfer flavoprotein dehydrogenase (etfdh), termed "xavier", closely mimics the characteristics observed in glutaric aciduria type II $[77,78]$. The mutant exhibited mitochondrial dysfunction, abnormal motility, typical metabolic profiles of fatty acids, and increased neural proliferation along with cell death. This model also provided the identification of the PPARG-ERK pathway as a potential target, where specifically peroxisome proliferator-activated receptor gamma (PPARG) antagonists were found to ameliorate neural symptoms such as observed paralysis in etfdh zebrafish mutants.

\subsection{Other Amino Acid Disorders}

The knockdown approach has also been used to create a zebrafish model for 3-methylglutaconic aciduria/Barth syndrome, an X-linked disorder, with organic aciduria, cardiomyopathy, and growth retardation. This model was effectively used to mimic the patient's phenotypes and can be used to understand disease mechanisms [79]. Furthermore, in a knockdown based zebrafish model for prolidase deficiency, heart defects were validated which were previously observed in a mouse mutant [80].

\section{Neurotransmission}

Monoamine neurotransmitter disorders have been of high interest for pediatricians and scientists alike for their fundamental role in neural development and function. Studies identified tyrosine hydroxylase deficiency, tryptophan hydroxylase deficiency, and phenylalanine hydroxylase deficiency (also known as Phenylketonuria or PKU) in their role for the synthesis of fundamental neurotransmitters precursors L-DOPA, 5-HT, and amino acids, respectively. Considering this long-standing research interest, many efficient models, including mouse and cell culture, and efficient patient analysis have already been established. This holds true, especially regarding PKU. Nonetheless, researchers have 
investigated neurotransmitter deficiencies in zebrafish, especially for pathways surrounding the neurotransmitter synthesis and the cofactor tetrahydrobiopterin $\left(\mathrm{BH}_{4}\right)$ pathway.

\subsection{Aromatic L-Amino Acid Decarboxylase (AADC) Deficiency}

AADC-deficiency is a neuro-metabolic disorder resulting in developmental delay, hypotonia, and dystonia, along with a depletion of biogenic amines such as dopamine and serotonin. A zebrafish model has been designed to target the gene dopa decarboxylase $(d d c)$, which actively catalyzes the synthesis of dopamine and serotonin [81]. Pharmacological inhibition and knockdown based approaches of $d d c$ activity in zebrafish, strikingly resulted in AADC-deficiency exhibiting clinical manifestations, including developmental delay, seizures, and abnormal swimming behavior. Notably, altering $d d c$ levels in zebrafish caused abnormal dopaminergic neuronal patterning of the midbrain, which likely affects CNS function.

\subsection{Atypical PKU/BH $\mathrm{BH}_{4}$ Deficiency}

Dihydropteridine reductase (DHPR) deficiency causes severe symptoms in children, including developmental delay, hypotonia, seizures, microcephaly, and hyperphenylalaninemia. There are highly conserved DHPR homologs in zebrafish. A recent study in zebrafish reported that two DHPR homologs, qpdra, and qdprb1 act on separate pathways [82]. On one hand, qdpra was linked to the production of $\mathrm{BH}_{4}$ in liver and melanocytes and the zebrafish qdpra loss-of-function model replicates the metabolic phenotype in patients, including hyperphenylalaninemia. On the other hand, $q d p r b 1$ is required for neural crest differentiation and proliferation without regulating $\mathrm{BH}_{4}$ metabolism. Zebrafish qdprb1 knockdown resulted in small brains compared to the brain atrophy and neural symptoms in patients. It is proposed that human DHPR may function in both pathways, resulting in the very severe phenotype seen in DHPR deficiency patients.

\subsection{Hyperekplexia}

Glycinergic synaptic transmission mediated by pentameric glycine receptors (GlyR) is essential in vertebrate CNS. Mutations that result in altered aggregation of glycine receptors cause startle disease, also known as hyperekplexia. A zebrafish mutant termed "bandoneon" carrying a mutation in the GlyR $\beta$-subunit ( $g l r b b)$ effectively mirrors the human phenotype of hyperekplexia. The zebrafish "bandoneon" mutant has absent glycinergic neurotransmission and concurrent abnormal tactile response in form of bilateral contractions [83]. Other mutants such as one termed "shocked", carrying mutations in the glycinergic transporter 1 gene (slc6a9), appear with similar phenotypes [84]. Detailed analysis of the "bandoneon" mutant has shown that all known 7 alleles act with varying sensitivity to glycine [85]. A recent study has created knockouts of all GlyR $\alpha$-subunits [86]. Due to identified functional redundancy in glr2, glra3, glra $4 a$, glra $4 b$ mutants showed no locomotive phenotype. However, the "hitch" zebrafish mutant line carrying a mutation in glra1 displays motor dysfunction in form of reduced activity and coordination. The availability of various mutant lines in zebrafish is of great interest for future investigation of glycinergic transmission and hyperekplexia.

\section{Metabolism of Vitamins and Co-Factors}

\section{DHFR Deficiency}

Dihydrofolate reductase (DHFR) is required for the regulation of intracellular folate homeostasis. DHFR deficiency results in megaloblastic anemia and neurological symptoms, including cerebellar atrophy, epilepsy, and retardation in patients. A zebrafish knockdown model for DHFR deficiency resulted in cardiac malformations which could be recovered by hand 2 overexpression [87]. Another approach to study $\mathrm{dhfr}$ deficiency in zebrafish is by using the specific DHFR inhibitor, methotrexate (MTX) $[88,89]$. Supplementation of folic acid could compensate for the effects on cardiac development in zebrafish exhibiting features of $d h f r$ deficiency [90]. The knockdown of $d h f r$ was also shown to regulate 
more fundamental pathways such as the hedgehog pathway, resulting in decreased proliferation and increased cell death [91]. A complete analysis of the folate pathway showed its role in early zebrafish development and supported the presentation of phenotypes upon $d h f r$ deficiency [92]. Recently, $d h f r$ transgenic lines have become available to identify expression dynamics [93]. Zebrafish $d h f r$ has also been used to investigate chaperone assisted refolding [94]. Furthermore, a light-inducible drug for timed inhibition of DHFR is available and could be used for further investigations in zebrafish [95]. Using various approaches, DHFR deficiency can effectively be investigated in zebrafish.

\section{Urea Cycle Disorders}

\section{Hyperammonemia}

Hyperammonemia is the direct consequence of urea cycle disorders. Among urea cycle disorders are ornithine transcarbamylase deficiency, arginase deficiency, and citrullinemia. The high levels of ammonia result in severe neurotoxicity, coma, and death [96]. As the enzyme deficiency results in the accumulation of a toxic compound, zebrafish can be used to mimic the acute accumulation of ammonia. A successful zebrafish model for hyperammonemia was reported, where it was shown that exposing larvae to increasing levels of ammonia in media, resulted in increasing lethality due to severe neurotoxicity [97]. Treatment with drugs commonly used in hyperammonemia to target the neurotoxicity observed in glutamatergic neurons and astrocytes showed an efficient delay in lethality. A recent study validated the model to investigate the role of acute hyperammonemia and identified a promising drug target by irreversible inhibition of ornithine aminotransferase using 5-fluoromethylornithine, efficiently recovering mortality in larvae [98]. This drug target is a promising approach to treat hyperammonemia and will likely be further investigated in the future. Follow up studies underlined the necessity for efficient intervention during hyperammonemia, by showing that prolonged hyperammonemia depleted ATP levels and resulted in bioenergetic failure [99]. Furthermore, the zebrafish model displayed decreased glutamate levels along with increased levels of gamma-aminobutyric acid (GABA), suggesting this model as a promising tool for future high-throughput drug screening [100].

\section{Carbohydrate Metabolism}

The body is dependent on effective energy storage. Glucose is stored as glycogen, primarily in the liver, skeletal muscle, and brain. Various types of glycogen storage disorders are caused by a deficiency in the glycogen metabolism pathways and vary from very mild to severe [101,102].

\subsection{Glycogen Storage Disease Type II/Pompe Disease}

Glycogen storage disease type II, also termed Pompe disease, is caused by mutations in the acid alpha-glucosidase (GAA) gene. The initial zebrafish model designed to disrupt gaa function failed to display the severity of symptoms seen in patients [103]. However, mild symptoms and excessive glycogen accumulation could be observed, which in this case could help identify underlying compensating mechanisms. However, a null mutant may be ineffective in investigating the disease phenotype, as patients often have remaining enzyme activity.

Along these lines, a very recent hypomorphic zebrafish model showed a greater resemblance to Pompe disease phenotypes such as glycogen accumulation in lysosomes and muscle stiffness. Furthermore, the study identified 3-bromopyruvic acid (3-BrPA) as a new compound ameliorating some of the observed symptoms, proposing a novel model to screen potential therapeutic interventions [104].

\subsection{Glycogen Storage Disease Type XI/Fanconi-Bickel Disease}

Fanconi-Bickel disease is caused by mutations in the gene of glucose transporter 2, SLC2A2, a gene that is exceptionally well conserved in zebrafish in sequence, structure, and function [105]. A knockdown model was used to analyze the role of $s l c 2 a 2$ in zebrafish brain development [106]. 
Hypomorphic zebrafish had decreased glucose uptake and increased cell apoptosis in the brain. Specifically, neural precursor markers of glutamatergic and GABAergic neurons were decreased due to glucose deprivation. This model can be used for investigating potential therapies for Fanconi-Bickel disease.

\subsection{Glucose-6-Phosphate Dehydrogenase (G6PD) Deficiency}

Studying G6PD deficiency in mice has been challenging as the knockout model resulted in embryonic lethality [107]. This prompted an analysis in zebrafish to test for a more efficient model. The initial model using morpholinos mimicked the patients' symptoms, which when challenged with oxidative stressors 1-naphthol, menthol, or primaquine caused severe heart edemas and hemolysis [108]. This effective readout for oxidative stress was used in a recent study with a chloroquine induced stress test, as well as a $g 6 p d$ F0 CRISPR/Cas9 model to show an effective reduction of oxidative stress using a small compound, AG1 [109]. The hypomorphic model, together with cell culture experiments, has also been used to understand the underlying early mechanisms. The study showed that the downregulation of G6PD dysregulated the $\mathrm{SMAD} / \mathrm{miR} 200 \mathrm{~b}$ axis required in affected key embryological pathways such as the epithelial-mesenchymal transition (EMT). E-Cadherin was sufficient to recover the observed embryological phenotype, giving G6PD a regulatory role during EMT together with $\mathrm{SMAD} / \mathrm{miR} 200 \mathrm{~b}[110]$.

\subsection{Galactosemia}

Galactosemia is caused by galactose-1-phosphate uridylyltransferase (GALT) deficiency, resulting in the toxic accumulation of galactose metabolites which need to be countered with an appropriate diet [111]. A TALEN mediated zebrafish knockout model of galt [112], acts as a supplemental model to the known mouse models [113,114]. The galt loss-of-function zebrafish model replicated the patients' metabolic phenotype with the accumulation of galactose-1-phosphate (Gal-1-P) upon exposure to galactose. Zebrafish not exposed to galactose developed normally. However, fish had reduced motor activity as well as reduced fertility, in line with the neurological, motor, and gonad related phenotype seen in classical galactosemia [115-117]. In a study using the same zebrafish KO model, there were no observed differences in UDP-galactose (UDP-Gal) or UDP-glucose (UDP-Glc) levels compared to controls, which suggests that the pathogenic cause of galactosemia is more extensive than UDP-Gal and UDP-Glc level alterations [118].

\subsection{GLUT1 Deficiency}

Abrogation of the glucose transporter 1 (glut1) in zebrafish by targeted knockdown results in CNS abnormalities that can be rescued by co-injection of human GLUT1 mRNA [119]. In line with the human phenotype, hypomorphic zebrafish had decreased glucose uptake that resulted in increased cell death. The neurodegenerative effect could be ameliorated by reducing proapoptotic Bcl-2-antagonist-of-cell-death (Bad) protein levels, yet glucose transport was not improved. This model can help to understand the role of glucose metabolism in cell death in GLUT1 deficiency.

\section{Lipoprotein Metabolism}

The proper regulation of lipoprotein metabolism is essential for lipid transport and homeostasis in the body. Lipoproteins are composed of a hydrophobic and hydrophilic portion including building blocks such as triglycerides or cholesterols. Apolipoprotein coated particles can act as ligands and/or cofactors. An effective model organism will amplify the knowledge obtained from cell culture data to multisystemic phenotypes and developmental effects. Zebrafish tools and transgenic lines are available that simplify the investigation of lipid processing, such as Oil-Red-O. Another method involves the use of fluorescently labeled lipids used to track both lipid metabolism and transport in vivo [120].

Dyslipidemias are commonly associated with the high-risk factor atherosclerosis. Zebrafish have proven a valuable model in understanding the underlying pathways and the models have been 
extensively reviewed [121,122]. Here, we will give an update on recent advances and reprise some highlights revealed by the zebrafish model.

\subsection{Hypercholesterolemia}

Familial hypercholesterolemia is one of the most common lipoprotein deficiencies causing atherosclerosis and is caused by mutations in the low-density lipoprotein (LDL) receptor (LDLR). Even though a mouse model exists that effectively mimics the patient's phenotype [123], a zebrafish model may prove useful for efficient and rapid drug screening. An initial hypomorphic zebrafish model for ldlr confirmed the conservation of function, showing increased LDL-cholesterol along with liver deposits in vasculature and liver [124]. A CRISPR/Cas9 ldlr zebrafish mutant may however serve as a better model for high-throughput drug screening [125]. The ldlr zebrafish mutant displayed hypercholesterolemia which is aggravated with a short period of high cholesterol diet (HCD), as well as the sterol regulatory element-binding protein 2 (Srebp-2) pathway activation. Furthermore, treatment of these mutants with an inhibitor of apolipoprotein B (ApoB) secretion showed reduced lipid accumulation.

Induction of hypercholesteremia in zebrafish by feeding with an HCD can be used to investigate both their effects as well as possible treatment approaches. HCD induces endothelial inflammation along with peroxisome proliferator-activated receptor-gamma ( ppar $\gamma$ ) downregulation prior to lipid accumulation and atherosclerosis. Treatment with an agonist to PPAR $\gamma$ ameliorated the phenotype [126]. A study using berbamine identified its anti-hypercholesterolemic and hepatoprotective effect [127]. The hypercholesteremia model has also been used to identify novel antihyperlipidemic compounds, such as ginsenosides as a potential clinical tactic [128]. Finally, zebrafish, in addition to providing insights to novel therapeutic approaches, can also be used to understand the adverse effects of drugs already in use, such as statins, that are the major drug prescribed for hyperlipidemias [129].

\subsection{Hypertriglyceridemia}

A deficiency in the apolipoprotein C2 (APOC2) can be causative of hypertriglyceridemia. An apoc2 zebrafish mutant developed severe hypertriglyceridemia, chylomicronemia, and reduced lipase activity all in line with human patients [130]. Furthermore, overgrowth of the pancreas, as well as lipid accumulation in the vasculature indicating atherosclerosis, make this model a successful representative for future investigations.

\section{Congenital Disorders of Glycosylation (CDG)}

\subsection{Pmm2-CDG}

CDG are disorders involving an underlying deficiency in the modification of proteins by sugar moieties. Mutations in phosphomannomutase 2 (PMM2), the most common underlying genetic cause [131], have been previously investigated in numerous model organisms including C. elegans [132], X. laevis [133], and S. cerevisiae [134]. PMM2-CDG constitutes for roughly $80 \%$ of all CDG cases and currently has no successful therapeutic intervention. A zebrafish knockdown model validated the role of pmm2 in the early neural and craniofacial development in zebrafish and was consistent with symptoms seen in CDG patients [135]. A zebrafish model [136], with a hypomorphic pmm2 mutation, was recently developed and it successfully replicated aspects of the disease. This model identified underlying endoplasmic reticulum (ER) stress resulting in the activation of nuclear factor erythroid 2-related factor 2 (Nrf2), mediated by the pERK pathway. While the study with this model did not identify a novel drug target, it confirmed that the underlying mechanisms in PMM2-CDG are more extensive than what is currently known about the involved pathways and may open novel treatment approaches. 


\section{2. $M P I-C D G$}

A morpholino based study focusing on the deficiency of phosphomannose isomerase (mpi), in zebrafish indicated the important role of early intervention [137]. As the mouse model is embryonic lethal [138], the knockdown approach in zebrafish was effectively used to study MPI-CDG. The phenotypes in this MPI-CDG zebrafish model included small eyes, pericardial edema, and small liver. In line with MPI-CDG being the only treatable CDG, mannose supplementation was sufficient to restore glycosylation levels and rescue the phenotype observed in the morphants. Notably, the supplementation was only effective if given within the first $24 \mathrm{hpf}$.

\section{3. $P G M 3-C D G$}

A study combining X. laevis, D. melanogaster and D. rerio provided a more fundamental developmental defect in correlation to UDP-GlcNAc, the building blocks of N-glycosylation [139]. The experiments showed that interfering with the UDP-GLcNAc glycosylation salvage pathway results in defective Wnt signaling. The abnormal UDP-GLcNAc pool may be in line with the mutations in phosphoglucomutase (PGM3) and phenotypes of PGM3-CDG patients [140,141].

\subsection{TMEM165-CDG}

Another study focusing on CDG showed the role of transmembrane protein 165 (tmem165) in the development of zebrafish craniofacial cartilage and osteoblast differentiation [142]. These results are in line with observed osteopenia or osteoporosis in TMEM-165-CDG patients [143]. The experiments particularly showed that both craniofacial abnormalities and $\mathrm{N}$-glycosylation deficiency were effectively rescued by co-injection of zebrafish wildtype tmem 165 mRNA. However, the phenotype could not be recovered with zebrafish tmem $165 \mathrm{mRNA}$ carrying a conserved patient mutation. This study established zebrafish as an effective model for TMEM165-CDG and for investigating the underlying mechanisms.

\subsection{TRAPPC11-CDG}

A genetic screen of 297 zebrafish lines identified the mutant with a gene-trap cassette inserted into the novel gene, originally termed "foie gras", as an effective model for liver disease, presenting with hepatomegaly, steatosis, and increased hepatocyte death [144]. Further studies linked the model to unfolded protein response (UPR) activation and ER stress. Close similarity to tunicamycin treated zebrafish resulted in the first speculation towards glycosylation [145]. The gene "foie gras" was identified as an ortholog of the transport protein particle complex 11 (TRAPPC11) and patients were initially linked to limb-girdle muscular dystrophy and steatosis [146]. Following investigations using a zebrafish mutant identified a striking defect in protein glycosylation, specifically the reduction of lipid-linked-oligosaccharides (LLO) [147]. The effect on UPR was mimicked by inhibiting LLO synthesis, placing the glycosylation defect upstream of UPR. Due to the studies performed in zebrafish, TRAPPC11 mutations have been validated as one of the underlying genetic causes in CDG patients $[148,149]$.

\section{Energy and Pyruvate Metabolism}

\section{Pyruvate Dehydrogenase (PDH) Complex}

PDH complex deficiencies are often severe with poor prognosis. Symptoms include developmental delay, abnormal brain development, encephalopathy, epilepsy, peripheral neuropathy, and congenital lactic acidosis. Genetic mutations underlying the disorder have been found in PDH1 (E1 subunit), dihydrolipoamide acetyltransferase (DLAT) (E2 subunit), and dihydrolipoamide dehydrogenase (DLD) (E3 subunit). An effective animal model is of great value in the investigation of treatments and their effectiveness. A first zebrafish model was identified and termed "no optokinetic response $a$ " mutant, which carries a mutation in the E2 subunit $[150,151]$. In line with the diagnostic indicators, mutant fish present with increased lactate and pyruvate. The lactic acidosis could be countered successfully 
with a ketogenic diet in fish, improving both neurological aspects and survival. A ketogenic diet is also the suggested intervention for patients affected by PDH complex deficiency [152]. Retracting the ketogenic diet from zebrafish resulted in rapidly occurring lethality [150]. Another mutant termed "noir" contains a mutation in $p d h 1 b$, the E1 $\beta$ subunit of the PDH complex [153]. The mutant displayed loss of vision, a lower number of cholinergic amacrine cells in the retina, and no response to light as screened by ERG at $7 \mathrm{dpf}$. Similar to the E2 mutant, a ketogenic diet ameliorated the severity and improved survival of the mutant. Both mutants provided successful underlining of the importance of early and consistent intervention with a ketogenic diet and will be an incredibly useful tool in future testing for ketogenic compounds or drugs. In fact, phenylbutyrate has been identified to regulate PDH complex activity by inhibiting pyruvate dehydrogenase kinase and increasing levels of activated PDH complex by phosphorylation of the E1 subunit [154]. Treatment of the "no optokinetic response a" mutant with phenylbutyrate, showed correction of locomotor and biochemical alterations.

\section{Lysosomal Storage Disorders}

Lysosomal storage disorders present one of the largest clusters of IEM, covering over 70 genetic deficiencies [155]. While each disease by itself is considered rare to extremely rare, taken together lysosomal storage disorders have a frequency of 1 in 5000-7700 newborns [156,157]. Many of these disorders have been investigated in zebrafish due to the high evolutionary conservation of genes and proteins between zebrafish and humans. Furthermore, the model has particular advantages such as simple stainings and compound tracking, such as lysotracker, as well as specific transgenic lines that have been generated to track lysosomal processing $[157,158]$.

Lysosomal storage disorders including types of neuronal ceroid lipofuscinoses (NCL), sphingolipidoses, and mucopolysaccharidosis (MPS) in the zebrafish model have just recently been extensively reviewed, therefore we will only highlight some of the most recent and striking advances [159].

\subsection{Gaucher's Disease}

Gaucher's disease is caused by mutations in the glucocerebrosidase gene 1 (GBA1) and is the most common lysosomal storage disorder with an incidence rate of 1:40,000 [160]. The deficiency results in the accumulation of glucocerebrosides in lysosomes causing splenomegaly, blood disorders, and skeletal disorders. Gaucher's disease is categorized into three types: type I (no neurological symptoms), type II (early-onset neurodegeneration), and type III (late-onset neurological symptoms) [161]. Even with type I presenting without major neurological symptoms the occurrence of Parkinson's disease is increased by 26-fold in Gaucher's disease patients [162]. A TALEN loss-of-function zebrafish model was the first vertebrate model to effectively mirrors the Gaucher's disease phenotype in both visceral and neural tissues, making it an excellent model for drug screening [163]. Strikingly in this study, loss of dopaminergic neurons in the brain could be determined as alpha-synuclein independent, as zebrafish lack the human alpha-synuclein counterpart $[163,164]$. Neurodegeneration was likely associated with non-alpha-synuclein proteinopathy preceded by microglial activation, 'Gaucher like cell' invasion, and early increase in miR-155 expression [163]. A more recent study has investigated the involvement of inflammation marker miR-155, in the zebrafish model [165]. The study was able to validate the increase in miR-155 in mammalian models of Gaucher's disease. Furthermore, a $g b a 1^{-/} / m i R-155^{-/}$double mutant did neither rescue the inflammation nor disease progression, concluding that miR-155 is not a promising therapeutic target. Another study using both mutants and a knockdown approach investigated the effect of gba1 deficiency on bone formation. The results showed a reduction in osteoblast differentiation markers and a negative regulation of the canonical Wnt pathway. Therewith, it proposed an intriguing role of the Wnt pathway in the skeletal abnormalities in Gaucher's disease [166]. Recent studies have used the efficiency of the zebrafish to further develop efficient models and understand the underlying mechanisms. Chemical studies have developed 
novel specific $g b a 1$ inhibitors based on cyclophellitol [167]. Another study has also used zebrafish to investigate the role of the $g b a 1$ homolog $g b a 2$ in a CRISPR/Cas9 model [168].

\subsection{Niemann-Pick Disease C (NPC)}

NPC is characterized by the accumulation of glycolipids and cholesterol in lysosomes, mediated by a deficiency in NPC1 (95\% of cases) or NPC2 required for proper intracellular cholesterol trafficking [169-171]. Patients with NPC present with neonatal jaundice, liver disease up to liver failure, ataxia, seizures, and progressing neurological problems [172-174].

In a CRISPR/Cas9 mediated knockout model for NPC, $n p \mathrm{c1}^{-/-}$zebrafish mutants had increased lethality prior to 6 months of age and striking growth retardation $[175,176]$. Homozygous mutants presented commonly with larger, vacuole-like structures and a strong signal for unesterified cholesterol, a key hallmark of NPC. Increased unesterified cholesterol was also previously shown in a knockdown model for NPC [177]. Another knockdown model also showed hematological defects including thrombocytopenia and anemia [178]. Furthermore, $n p c 1^{-/-}$mutants present with similar neurological abnormalities as patients, including axonal spheroids and disorganized Purkinje cells $[175,176,179]$. The knockout model may serve as an effective drug-screen model, as LysoTracker Red staining (for acidic organelles) and filipin staining (for unesterified cholesterol) are increased in early development. Drug screens with 2-hydroxypropyl- $\beta$-cyclodextrin ( $2 \mathrm{HP} \beta C D$ ), a compound confirmed in other models and tested in clinical trials, reduced staining in $\mathrm{npc}^{-/-}$mutants confirming the efficacy of the model $[175,180,181]$.

\subsection{Farber Disease}

Farber disease is caused by loss of function in acid ceramidase, ASAH1, resulting in the accumulation of ceramide, causing a multisystemic phenotype associated with early mortality [182]. Deficiencies in this enzyme have also been associated with the development of spinal muscular atrophy with progressive myoclonic epilepsy (SMA-PME) [183].

A first zebrafish knockdown model showed a loss of motor neuron axonal branching [184]. A more recent study designed a CRISPR/Cas9 knockout for both orthologues asah1a and asah1b, successfully mimicking the characteristics of Farber disease [185]. Using parallel reaction monitoring (PRM)-based liquid chromatography-mass spectrometry (LC-MS) method for ceramide analysis, it was shown that a double knockout is required to significantly increase ceramide content in the zebrafish brain, as either asah1a or $a s a h 1 b$ was sufficient to maintain physiological levels. Detailed analysis of the double knockout mutant revealed a clear trend towards the accumulation of ceramides with a higher number of carbons in the long-chain base and less in the acyl-chains of the sphingolipids, indicating a possibility for more complex compensatory mechanisms.

\subsection{Mucopolysaccharidosis (MPS)}

MPS is a lysosomal storage disorder resulting in the accumulation of glycosaminoglycans (GAGs). Seven different types have been characterized, connected to 11 enzymes [186]. Symptoms vary widely from neurological symptoms to skeletal abnormalities [187]. Currently, treatment options focus on enzyme replacement therapy, but with the advances in gene editing and efficient zebrafish models, other treatment strategies may arise [188]. 
Table 1. Summary of Zebrafish "inborn errors of metabolism" (IEM) models.

\begin{tabular}{|c|c|c|c|c|}
\hline Metabolism & Disorders & Zebrafish Genes & Approach & Reference \\
\hline \multirow{5}{*}{$\begin{array}{c}\text { Amino acid and peptide } \\
\text { metabolism }\end{array}$} & $\begin{array}{l}\text { Maple syrup urine } \\
\text { disorder }\end{array}$ & $d b t$ & $\begin{array}{l}\text { CRISPR/Cas9; } \\
\text { Metabolite } \\
\text { exposure }\end{array}$ & {$[64,68]$} \\
\hline & Methylmalonic acidemia & mmut, mmachc & CRISPR/Cas9 & [73-76] \\
\hline & Glutaric aciduria type II & etfdh & CRISPR/Cas9 & {$[77,78]$} \\
\hline & Barth Syndrome & taz & Morpholino & [79] \\
\hline & Prolidase deficiency & pepd & Morpholino & [80] \\
\hline \multirow{3}{*}{ Neurotransmission } & AADC deficiency & $d d c$ & $\begin{array}{l}\text { Inhibitor, } \\
\text { Morpholino }\end{array}$ & [81] \\
\hline & DHPR deficiency & qdpra/qdprb1/qdprb2 & Morpholino & [82] \\
\hline & Hyperekplexia & glra1, glrbb & ENU & [83-86] \\
\hline $\begin{array}{l}\text { Metabolism of Vitamins } \\
\text { and Co-factors }\end{array}$ & DHFR deficiency & $d h f r$ & $\begin{array}{l}\text { Inhibitor, } \\
\text { Morpholino }\end{array}$ & [87-92] \\
\hline Urea Cycle Disorders & Hyperammonemia & / & $\begin{array}{l}\text { Metabolite } \\
\text { exposure }\end{array}$ & [97-100] \\
\hline \multirow{5}{*}{$\begin{array}{l}\text { Carbohydrate } \\
\text { Metabolism }\end{array}$} & $\begin{array}{l}\text { GSD Type II/Pompe } \\
\text { disease }\end{array}$ & $g a a$ & Morpholino & {$[103,104]$} \\
\hline & $\begin{array}{c}\text { GSD type } \\
\text { XI/Fanconi-Bickel } \\
\text { disease }\end{array}$ & slc $2 a 2$ & Morpholino & [106] \\
\hline & G6PD deficiency & $g 6 p d$ & $\begin{array}{l}\text { CRISPR/Cas9; } \\
\text { Morpholino }\end{array}$ & [108-110] \\
\hline & Galactosemia & galt & TALEN & {$[112,118]$} \\
\hline & GLUT1 deficiency & glut1 & Morpholino & [119] \\
\hline \multirow[t]{2}{*}{ Lipoprotein Metabolism } & Hypercholesterolemia & $l d l r$ & $\begin{array}{c}\text { CRISPR/Cas9, } \\
\text { Morpholino, Diet }\end{array}$ & [124-128] \\
\hline & Hypertriglyceridemia & apoc2 & CRISPR/Cas9 & [130] \\
\hline \multirow{4}{*}{$\begin{array}{l}\text { Congenital disorders of } \\
\text { glycosylation (CDG) }\end{array}$} & PMM2-CDG & pmm2 & ENU, Morpholino & {$[135,136]$} \\
\hline & MPI-CDG & mpi & Morpholino & [137] \\
\hline & TMEM165-CDG & tmem165 & Morpholino & [142] \\
\hline & TRAPPC11-CDG & trappc11c & gene-trap cassette & [144-147] \\
\hline $\begin{array}{l}\text { Energy and Pyruvate } \\
\text { Metabolism }\end{array}$ & $\begin{array}{l}\text { Pyruvate dehydrogenase } \\
\text { complex deficiency }\end{array}$ & dlat, $p d h 1 b$ & ENU & $\begin{array}{c}{[150,151,153,} \\
154]\end{array}$ \\
\hline \multirow{4}{*}{$\begin{array}{l}\text { Lysosomal Storage } \\
\text { Disorders }\end{array}$} & Gaucher's disease & $g b a 1$ & $\begin{array}{c}\text { TALEN; } \\
\text { CRISPR/Cas9; } \\
\text { Morpholino }\end{array}$ & {$[163,165-168]$} \\
\hline & Niemann-Pick disease C & $n p c 1$ & $\begin{array}{l}\text { CRISPR/Cas9; } \\
\text { Morpholino }\end{array}$ & [175-178] \\
\hline & Farber disease & asah1a, asah1b & $\begin{array}{l}\text { CRISPR/Cas9; } \\
\text { Morpholino }\end{array}$ & {$[184,185]$} \\
\hline & $\begin{array}{l}\text { MPS II/Hunter } \\
\text { Syndrome }\end{array}$ & $i d s$ & $\begin{array}{l}\text { CRISPR/Cas9; } \\
\text { Morpholino }\end{array}$ & [189-191] \\
\hline
\end{tabular}

\subsection{Mucopolysaccharidosis II (MPS II)/Hunter Syndrome}

MPS II or Hunter syndrome is an X-linked condition that is caused by a deficiency in the iduronate-2-sulfatase (IDS) enzyme. Patients present with several different symptoms ranging from respiratory tract dysfunctions to a collection of bone abnormalities termed dysostosis multiplex. [187]. An initial zebrafish knockdown model identified an increased $\operatorname{Tgf} \beta$ signaling associated with $i d s$ knockdown, affecting both craniofacial cartilage development and neural crest cells [189]. The same 
model was used to find an underlying Shh signaling downregulation and in turn $\mathrm{Wnt} / \beta$-Catenin upregulation, during heart development before the onset of GAG accumulation [190].

A new study in zebrafish using a CRISPR/Cas9 knockout, revealed deficient Fgf signaling in $2 \mathrm{dpf}$ zebrafish, that persists in adult bone tissue [191]. Key skeletal markers for mineralization, including os $x$ and bglap were significantly downregulated and adult zebrafish presented with skeletal abnormalities revealed by microCT analysis, showing that the signaling defects appear long before the skeletal symptom onset. Additionally, the study was able to validate the downregulated FGF targets (dups6 and pea3) in fibroblasts from Hunter syndrome patients. These studies showed that the underlying pathophysiology is not only caused by GAG accumulation, but by several misregulated pathways.

\section{Novel Therapeutic Intervention for Metabolic Disorders}

With one of the greatest advantages of zebrafish being high throughput drug screening capability, it is to be expected that the listed models will be used to uncover novel therapeutic interventions. Therapeutic interventions for metabolic disorders are often simple and at the same time inefficient. While IEM can result in metabolite deficiency, supplementation appears to be the subsequent approach. However, delivery is not always efficient, especially if crossing the blood-brain-barrier is required. Possible novel targets, as well as previously unknown underlying mechanisms, as shown in this review, have been identified using zebrafish models for disorders underlying hyperammonemia, hypercholesterolemia, PDH complex deficiency, and TRAPPC11C-CDG.

\section{Outlook}

The impact made on IEM by the zebrafish model is evident. Even more, the influence zebrafish studies had in the last decades in a great variety of diseases and their relevance for human treatment has been highlighted in numerous publications [159,192-197]. It is to be expected that the role of zebrafish will continue to grow for rare metabolic disorders, especially with the prospect of drug screening and the effectiveness of CRISPR/Cas9 editing. Furthermore, with the increasing number of novel mutations identified for underlying metabolic disorders by whole-exome/genome sequencing, the simplicity of the zebrafish model to easily validate the pathogenicity of genetic mutations and elucidate their roles in disease pathogenesis will likely encourage further cooperation between clinicians and scientists in the rare metabolic disorders field. The past has already shown that such collaboration can lead to the successful investigation of gene function up to therapeutic intervention. This will increase our knowledge not only on known metabolic functions, but likely identify novel pathways, previously uncharacterized. As the large variety of rare inherited metabolic disorders has sparked great interest in research, zebrafish will likely be key in testing novel approaches for treatment, including gene therapy. In an important note: IEM are often considered only pediatric diseases, but with improving diagnosis and treatment options, adult and long-term management will become a major focus of new studies, to improve not only mutation detection but also the quality of life.

Future studies will continue to use zebrafish and other model organisms for rare inherited metabolic disorders and play their part in contributing to novel drug targets, mechanisms, and treatment options.

Author Contributions: M.B. collected and analyzed the literature and wrote the manuscript. S.A.P. reviewed and edited the manuscript. M.B. performed all the experiments for the images presented in Figure 2. All authors have read and agreed to the published version of the manuscript.

Funding: This research was funded by the Canadian Foundation for Innovation (CFI) and Canadian Institutes of Health Research (CIHR) and a FRQS Junior 1 research scholar.

Conflicts of Interest: The authors declare no conflict of interest.

\section{References}

1. Garrod, A.E. Inborn Errors of Metabolism, 2nd ed.; Oxford University Press: Oxford, UK, 1923. 
2. Martins, A.M. Inborn errors of metabolism: A clinical overview. Sao Paulo Med. J. 1999, 117, $251-265$. [CrossRef] [PubMed]

3. Pampols, T. Inherited metabolic rare disease. Adv. Exp. Med. Biol. 2010, 686, 397-431. [CrossRef] [PubMed]

4. Yang, C.J.; Wei, N.; Li, M.; Xie, K.; Li, J.Q.; Huang, C.G.; Xiao, Y.S.; Liu, W.H.; Chen, X.G. Diagnosis and therapeutic monitoring of inborn errors of metabolism in 100,077 newborns from Jining city in China. BMC Pediatrics 2018, 18, 110. [CrossRef]

5. Applegarth, D.A.; Toone, J.R.; Lowry, R.B. Incidence of inborn errors of metabolism in British Columbia, 1969-1996. Pediatrics 2000, 105, e10. [CrossRef] [PubMed]

6. Hutchesson, A.C.; Bundey, S.; Preece, M.A.; Hall, S.K.; Green, A. A comparison of disease and gene frequencies of inborn errors of metabolism among different ethnic groups in the West Midlands, UK. J. Med. Genet. 1998, 35, 366-370. [CrossRef] [PubMed]

7. Keyfi, F.; Nasseri, M.; Nayerabadi, S.; Alaei, A.; Mokhtariye, A.; Varasteh, A. Frequency of Inborn Errors of Metabolism in a Northeastern Iranian Sample with High Consanguinity Rates. Hum. Hered. 2018, 83, 71-78. [CrossRef] [PubMed]

8. Sanderson, S.; Green, A.; Preece, M.A.; Burton, H. The incidence of inherited metabolic disorders in the West Midlands, UK. Arch. Dis. Child. 2006, 91, 896-899. [CrossRef]

9. Waters, D.; Adeloye, D.; Woolham, D.; Wastnedge, E.; Patel, S.; Rudan, I. Global birth prevalence and mortality from inborn errors of metabolism: A systematic analysis of the evidence. J. Glob. Health 2018, 8, 021102. [CrossRef] [PubMed]

10. Zhang, W.; Yang, Y.; Peng, W.; Chang, J.; Mei, Y.; Yan, L.; Chen, Y.; Wei, X.; Liu, Y.; Wang, Y.; et al. A 7-Year Report of Spectrum of Inborn Errors of Metabolism on Full-Term and Premature Infants in a Chinese Neonatal Intensive Care Unit. Front. Genet. 2019, 10, 1302. [CrossRef]

11. Vernon, H.J. Inborn Errors of Metabolism: Advances in Diagnosis and Therapy. JAMA Pediatr. 2015, 169, 778-782. [CrossRef]

12. Smith, L.D.; Willig, L.K.; Kingsmore, S.F. Whole-Exome Sequencing and Whole-Genome Sequencing in Critically Ill Neonates Suspected to Have Single-Gene Disorders. Cold Spring Harb. Perspect. Med. 2015, 6, a023168. [CrossRef] [PubMed]

13. Jelin, A.C.; Vora, N. Whole Exome Sequencing: Applications in Prenatal Genetics. Obstet. Gynecol. Clin. North Am. 2018, 45, 69-81. [CrossRef] [PubMed]

14. van Rijt, W.J.; Koolhaas, G.D.; Bekhof, J.; Heiner Fokkema, M.R.; de Koning, T.J.; Visser, G.; Schielen, P.C.; van Spronsen, F.J.; Derks, T.G. Inborn Errors of Metabolism That Cause Sudden Infant Death: A Systematic Review with Implications for Population Neonatal Screening Programmes. Neonatology 2016, 109, 297-302. [CrossRef] [PubMed]

15. Bennett, E.E.; Hummel, K.; Smith, A.G.; Longo, N. Acute Presentation and Management of the Encephalopathic Child With an Undiagnosed Inborn Error of Metabolism. J. Emerg. Med. 2019, 56, e5-e8. [CrossRef] [PubMed]

16. Romao, A.; Simon, P.E.A.; Goes, J.E.C.; Pinto, L.L.C.; Giugliani, R.; Luca, G.R.; Carvalho, F.L.C. Initial Clinical Presentation in Cases of Inborn Errors of Metabolism in a Reference Children's Hospital: Still a Diagnostic Challenge. Rev. Paul. Pediatr. 2017, 35, 258-264. [CrossRef] [PubMed]

17. Seymour, C.A.; Thomason, M.J.; Chalmers, R.A.; Addison, G.M.; Bain, M.D.; Cockburn, F.; Littlejohns, P.; Lord, J.; Wilcox, A.H. Newborn screening for inborn errors of metabolism: A systematic review. Health Technol. Assess 1997, 1, 1-95. [CrossRef]

18. Camp, K.M.; Lloyd-Puryear, M.A.; Huntington, K.L. Nutritional treatment for inborn errors of metabolism: Indications, regulations, and availability of medical foods and dietary supplements using phenylketonuria as an example. Mol. Genet. Metab. 2012, 107,3-9. [CrossRef]

19. Kabra, M. Dietary management of inborn errors of metabolism. Indian J. Pediatr. 2002, 69, 421-426. [CrossRef]

20. Ris, M.D.; Williams, S.E.; Hunt, M.M.; Berry, H.K.; Leslie, N. Early-treated phenylketonuria: Adult neuropsychologic outcome. J. Pediatr. 1994, 124, 388-392. [CrossRef]

21. McDonnell, G.V.; Esmonde, T.F.; Hadden, D.R.; Morrow, J.I. A neurological evaluation of adult phenylketonuria in Northern Ireland. Eur. Neurol. 1998, 39, 38-43. [CrossRef]

22. Wanders, R.J.A.; Vaz, F.M.; Ferdinandusse, S.; van Kuilenburg, A.B.P.; Kemp, S.; van Karnebeek, C.D.; Waterham, H.R.; Houtkooper, R.H. Translational Metabolism: A multidisciplinary approach towards 
precision diagnosis of inborn errors of metabolism in the omics era. J. Inherit Metab. Dis. 2019, 42, 197-208. [CrossRef] [PubMed]

23. McDonald, J.D. Production of mouse models for the study of human inborn errors of metabolism. Mol. Genet. Metab. 2000, 71, 240-244. [CrossRef] [PubMed]

24. Pronk, J.T.; van der Linden-Beuman, A.; Verduyn, C.; Scheffers, W.A.; van Dijken, J.P. Propionate metabolism in Saccharomyces cerevisiae: Implications for the metabolon hypothesis. Microbiology 1994, 140, 717-722. [CrossRef] [PubMed]

25. Struwe, W.B.; Hughes, B.L.; Osborn, D.W.; Boudreau, E.D.; Shaw, K.M.; Warren, C.E. Modeling a congenital disorder of glycosylation type I in C. elegans: A genome-wide RNAi screen for N-glycosylation-dependent loci. Glycobiology 2009, 19, 1554-1562. [CrossRef]

26. Hindle, S.; Hebbar, S.; Sweeney, S.T. Invertebrate models of lysosomal storage disease: What have we learned so far? Invert. Neurosci. 2011, 11, 59-71. [CrossRef]

27. de Voer, G.; Peters, D.; Taschner, P.E. Caenorhabditis elegans as a model for lysosomal storage disorders. Biochim. Biophys. Acta 2008, 1782, 433-446. [CrossRef]

28. Sellin, J.; Schulze, H.; Paradis, M.; Gosejacob, D.; Papan, C.; Shevchenko, A.; Psathaki, O.E.; Paululat, A.; Thielisch, M.; Sandhoff, K.; et al. Characterization of Drosophila Saposin-related mutants as a model for lysosomal sphingolipid storage diseases. Dis. Models Mech. 2017, 10, 737-750. [CrossRef]

29. Daenzer, J.M.; Fridovich-Keil, J.L. Drosophila melanogaster Models of Galactosemia. Curr. Top Dev. Biol. 2017, 121, 377-395. [CrossRef]

30. Vora, S.; Giger, U.; Turchen, S.; Harvey, J.W. Characterization of the enzymatic lesion in inherited phosphofructokinase deficiency in the dog: An animal analogue of human glycogen storage disease type VII. Proc. Natl. Acad. Sci. USA 1985, 82, 8109-8113. [CrossRef]

31. Katz, M.L.; Rustad, E.; Robinson, G.O.; Whiting, R.E.H.; Student, J.T.; Coates, J.R.; Narfstrom, K. Canine neuronal ceroid lipofuscinoses: Promising models for preclinical testing of therapeutic interventions. Neurobiol. Dis. 2017, 108, 277-287. [CrossRef]

32. Sewell, A.C.; Haskins, M.E.; Giger, U. Inherited metabolic disease in companion animals: Searching for nature's mistakes. Vet. J. (London, England: 1997) 2007, 174, 252-259. [CrossRef] [PubMed]

33. Schlegel, A.; Gut, P. Metabolic insights from zebrafish genetics, physiology, and chemical biology. Cell Mol. Life Sci. 2015, 72, 2249-2260. [CrossRef] [PubMed]

34. Streisinger, G.; Walker, C.; Dower, N.; Knauber, D.; Singer, F. Production of clones of homozygous diploid zebra fish (Brachydanio rerio). Nature 1981, 291, 293-296. [CrossRef] [PubMed]

35. Hruscha, A.; Krawitz, P.; Rechenberg, A.; Heinrich, V.; Hecht, J.; Haass, C.; Schmid, B. Efficient CRISPR/Cas9 genome editing with low off-target effects in zebrafish. Development 2013, 140, 4982-4987. [CrossRef] [PubMed]

36. Gagnon, J.A.; Valen, E.; Thyme, S.B.; Huang, P.; Akhmetova, L.; Pauli, A.; Montague, T.G.; Zimmerman, S.; Richter, C.; Schier, A.F. Efficient mutagenesis by Cas9 protein-mediated oligonucleotide insertion and large-scale assessment of single-guide RNAs. PLoS ONE 2014, 9, e98186. [CrossRef]

37. Ata, H.; Ekstrom, T.L.; Martinez-Galvez, G.; Mann, C.M.; Dvornikov, A.V.; Schaefbauer, K.J.; Ma, A.C.; Dobbs, D.; Clark, K.J.; Ekker, S.C. Robust activation of microhomology-mediated end joining for precision gene editing applications. PLoS Genet. 2018, 14, e1007652. [CrossRef]

38. Wierson, W.A.; Simone, B.W.; WareJoncas, Z.; Mann, C.; Welker, J.M.; Kar, B.; Emch, M.J.; Friedberg, I.; Gendron, W.A.C.; Barry, M.A.; et al. Expanding the CRISPR Toolbox with ErCas12a in Zebrafish and Human Cells. CRISPR J. 2019, 2, 417-433. [CrossRef]

39. Kimmel, C.B.; Ballard, W.W.; Kimmel, S.R.; Ullmann, B.; Schilling, T.F. Stages of embryonic development of the zebrafish. Dev. Dyn. 1995, 203, 253-310. [CrossRef]

40. Parichy, D.M.; Elizondo, M.R.; Mills, M.G.; Gordon, T.N.; Engeszer, R.E. Normal table of postembryonic zebrafish development: Staging by externally visible anatomy of the living fish. Dev. Dyn. 2009, 238, 2975-3015. [CrossRef]

41. Randlett, O.; Wee, C.L.; Naumann, E.A.; Nnaemeka, O.; Schoppik, D.; Fitzgerald, J.E.; Portugues, R.; Lacoste, A.M.B.; Riegler, C.; Engert, F.; et al. Whole-brain activity mapping onto a zebrafish brain atlas. Nat. Methods 2015, 12, 1039-1046. [CrossRef]

42. Rocha, M.; Singh, N.; Ahsan, K.; Beiriger, A.; Prince, V.E. Neural crest development: Insights from the zebrafish. Dev. Dyn. 2020, 249, 88-111. [CrossRef] [PubMed] 
43. Mueller, T.; Wullimann, M. Atlas of Early Zebrafish Brain Development: A Tool for Molecular Neurogenetics; Elsevier: Amsterdam, The Netherlands, 2005.

44. Howe, K.; Clark, M.D.; Torroja, C.F.; Torrance, J.; Berthelot, C.; Muffato, M.; Collins, J.E.; Humphray, S.; McLaren, K.; Matthews, L.; et al. The zebrafish reference genome sequence and its relationship to the human genome. Nature 2013, 496, 498-503. [CrossRef] [PubMed]

45. Taylor, J.S.; Braasch, I.; Frickey, T.; Meyer, A.; Van de Peer, Y. Genome duplication, a trait shared by 22000 species of ray-finned fish. Genome Res. 2003, 13, 382-390. [CrossRef] [PubMed]

46. Schauerte, H.E.; van Eeden, F.J.; Fricke, C.; Odenthal, J.; Strahle, U.; Haffter, P. Sonic hedgehog is not required for the induction of medial floor plate cells in the zebrafish. Development 1998, 125, 2983-2993. [PubMed]

47. Benchoula, K.; Khatib, A.; Jaffar, A.; Ahmed, Q.U.; Sulaiman, W.; Wahab, R.A.; El-Seedi, H.R. The promise of zebrafish as a model of metabolic syndrome. Exp. Anim. 2019, 68, 407-416. [CrossRef] [PubMed]

48. Salmi, T.M.; Tan, V.W.T.; Cox, A.G. Dissecting metabolism using zebrafish models of disease. Biochem. Soc. Trans. 2019, 47, 305-315. [CrossRef]

49. Zhang, Y.; Qin, C.; Yang, L.; Lu, R.; Zhao, X.; Nie, G. A comparative genomics study of carbohydrate/glucose metabolic genes: From fish to mammals. BMC Genom. 2018, 19, 246. [CrossRef]

50. Huang, S.M.; Xu, F.; Lam, S.H.; Gong, Z.; Ong, C.N. Metabolomics of developing zebrafish embryos using gas chromatography- and liquid chromatography-mass spectrometry. Mol. Biosyst. 2013, 9, 1372-1380. [CrossRef]

51. Dhillon, S.S.; Torell, F.; Donten, M.; Lundstedt-Enkel, K.; Bennett, K.; Rannar, S.; Trygg, J.; Lundstedt, T. Metabolic profiling of zebrafish embryo development from blastula period to early larval stages. PLoS ONE 2019, 14, e0213661. [CrossRef]

52. Sakai, C.; Ijaz, S.; Hoffman, E.J. Zebrafish Models of Neurodevelopmental Disorders: Past, Present, and Future. Front. Mol. Neurosci. 2018, 11, 294. [CrossRef]

53. Eimon, P.M.; Rubinstein, A.L. The use of in vivo zebrafish assays in drug toxicity screening. Expert Opin. Drug Metab. Toxicol. 2009, 5, 393-401. [CrossRef] [PubMed]

54. Yoganantharjah, P.; Gibert, Y. The Use of the Zebrafish Model to Aid in Drug Discovery and Target Validation. Curr. Top Med. Chem. 2017, 17, 2041-2055. [CrossRef] [PubMed]

55. Basnet, R.M.; Zizioli, D.; Taweedet, S.; Finazzi, D.; Memo, M. Zebrafish Larvae as a Behavioral Model in Neuropharmacology. Biomedicines 2019, 7, 23. [CrossRef] [PubMed]

56. Patten, S.A.; Aggad, D.; Martinez, J.; Tremblay, E.; Petrillo, J.; Armstrong, G.A.; La Fontaine, A.; Maios, C.; Liao, M.; Ciura, S.; et al. Neuroleptics as therapeutic compounds stabilizing neuromuscular transmission in amyotrophic lateral sclerosis. JCI Insight 2017, 2. [CrossRef] [PubMed]

57. Rennekamp, A.J.; Peterson, R.T. 15 years of zebrafish chemical screening. Curr. Opin. Chem. Biol. 2015, 24, 58-70. [CrossRef]

58. Costa, B.; Estrada, M.F.; Mendes, R.V.; Fior, R. Zebrafish Avatars towards Personalized Medicine-A Comparative Review between Avatar Models. Cells 2020, 9, 293. [CrossRef]

59. Usai, A.; Di Franco, G.; Colucci, P.; Pollina, L.E.; Vasile, E.; Funel, N.; Palmeri, M.; Dente, L.; Falcone, A.; Morelli, L.; et al. A Model of a Zebrafish Avatar for Co-Clinical Trials. Cancers 2020, 12, 677. [CrossRef]

60. Ozand, P.T.; Gascon, G.G. Organic acidurias: A review. Part 1. J. Child Neurol. 1991, 6, 196-219. [CrossRef]

61. Vaidyanathan, K.; Narayanan, M.P.; Vasudevan, D.M. Organic acidurias: An updated review. Indian J. Clin. Biochem. 2011, 26, 319-325. [CrossRef]

62. Yannicelli, S. Nutrition therapy of organic acidaemias with amino acid-based formulas: Emphasis on methylmalonic and propionic acidaemia. J. Inherit Metab. Dis. 2006, 29, 281-287. [CrossRef]

63. Strauss, K.A.; Morton, D.H. Branched-chain Ketoacyl Dehydrogenase Deficiency: Maple Syrup Disease. Curr. Treat Options Neurol. 2003, 5, 329-341. [CrossRef] [PubMed]

64. Friedrich, T.; Lambert, A.M.; Masino, M.A.; Downes, G.B. Mutation of zebrafish dihydrolipoamide branched-chain transacylase E2 results in motor dysfunction and models maple syrup urine disease. Dis. Models Mech. 2012, 5, 248-258. [CrossRef] [PubMed]

65. Vaz, R.L.; Outeiro, T.F.; Ferreira, J.J. Zebrafish as an Animal Model for Drug Discovery in Parkinson's Disease and Other Movement Disorders: A Systematic Review. Front. Neurol. 2018, 9, 347. [CrossRef] [PubMed]

66. Cornet, C.; Di Donato, V.; Terriente, J. Combining Zebrafish and CRISPR/Cas9: Toward a More Efficient Drug Discovery Pipeline. Front. Pharmacol. 2018, 9, 703. [CrossRef] [PubMed] 
67. Goldsmith, P. Zebrafish as a pharmacological tool: The how, why and when. Curr. Opin. Pharmacol. 2004, 4, 504-512. [CrossRef] [PubMed]

68. Wessler, L.B.; Farias, H.R.; Ronsani, J.F.; Candiotto, G.; Dos Santos, P.C.L.; de Oliveira, J.; Rico, E.P.; Streck, E.L. Acute exposure to leucine modifies behavioral parameters and cholinergic activity in zebrafish. Int. J. Dev. Neurosci. 2019, 78, 222-226. [CrossRef]

69. Oberholzer, V.G.; Levin, B.; Burgess, E.A.; Young, W.F. Methylmalonic aciduria. An inborn error of metabolism leading to chronic metabolic acidosis. Arch. Dis. Child. 1967, 42, 492-504. [CrossRef]

70. Chace, D.H.; DiPerna, J.C.; Kalas, T.A.; Johnson, R.W.; Naylor, E.W. Rapid diagnosis of methylmalonic and propionic acidemias: Quantitative tandem mass spectrometric analysis of propionylcarnitine in filter-paper blood specimens obtained from newborns. Clin. Chem. 2001, 47, 2040-2044. [CrossRef]

71. Fenton, W.A.; Gravel, R.A.; Rosenblatt, D.S. The Metabolic and Molecular Bases of Inherited Disease; Scriver, C.R., Beaudet, A.L., Sly, W.S., Valle, D., Eds.; McGraw-Hill: New York, NY, USA, 2001; pp. 2165-2193.

72. Peters, H.; Nefedov, M.; Sarsero, J.; Pitt, J.; Fowler, K.J.; Gazeas, S.; Kahler, S.G.; Ioannou, P.A. A knock-out mouse model for methylmalonic aciduria resulting in neonatal lethality. J. Biol. Chem. 2003, 278, 52909-52913. [CrossRef]

73. Luciani, A.; Schumann, A.; Berquez, M.; Chen, Z.; Nieri, D.; Failli, M.; Debaix, H.; Festa, B.P.; Tokonami, N.; Raimondi, A.; et al. Impaired mitophagy links mitochondrial disease to epithelial stress in methylmalonyl-CoA mutase deficiency. Nat. Commun. 2020, 11, 970. [CrossRef]

74. Luciani, A.; Devuyst, O. Methylmalonyl acidemia: From mitochondrial metabolism to defective mitophagy and disease. Autophagy 2020, 16, 1159-1161. [CrossRef] [PubMed]

75. Chen, Z.; Berquez, M.; Luciani, A. Mitochondria, mitophagy, and metabolic disease: Towards assembling the puzzle. Cell Stress 2020, 4, 147-150. [CrossRef] [PubMed]

76. Sloan, J.L.; Achilly, N.P.; Arnold, M.L.; Catlett, J.L.; Blake, T.; Bishop, K.; Jones, M.; Harper, U.; English, M.A.; Anderson, S.; et al. The vitamin B12 processing enzyme, mmachc, is essential for zebrafish survival, growth and retinal morphology. Hum. Mol. Genet. 2020. [CrossRef] [PubMed]

77. Song, Y.; Selak, M.A.; Watson, C.T.; Coutts, C.; Scherer, P.C.; Panzer, J.A.; Gibbs, S.; Scott, M.O.; Willer, G.; Gregg, R.G.; et al. Mechanisms underlying metabolic and neural defects in zebrafish and human multiple acyl-CoA dehydrogenase deficiency (MADD). PLoS ONE 2009, 4, e8329. [CrossRef] [PubMed]

78. Panzer, J.A.; Gibbs, S.M.; Dosch, R.; Wagner, D.; Mullins, M.C.; Granato, M.; Balice-Gordon, R.J. Neuromuscular synaptogenesis in wild-type and mutant zebrafish. Dev. Biol. 2005, 285, 340-357. [CrossRef] [PubMed]

79. Khuchua, Z.; Yue, Z.; Batts, L.; Strauss, A.W. A zebrafish model of human Barth syndrome reveals the essential role of tafazzin in cardiac development and function. Circ. Res. 2006, 99, 201-208. [CrossRef]

80. Jung, S.; Silvius, D.; Nolan, K.A.; Borchert, G.L.; Millet, Y.H.; Phang, J.M.; Gunn, T.M. Developmental cardiac hypertrophy in a mouse model of prolidase deficiency. Birth Defects Res. Clin. Mol. Teratol. 2011, 91, $204-217$. [CrossRef]

81. Shih, D.F.; Hsiao, C.D.; Min, M.Y.; Lai, W.S.; Yang, C.W.; Lee, W.T.; Lee, S.J. Aromatic L-amino acid decarboxylase (AADC) is crucial for brain development and motor functions. PLoS ONE 2013, 8, e71741. [CrossRef]

82. Breuer, M.; Guglielmi, L.; Zielonka, M.; Hemberger, V.; Kolker, S.; Okun, J.G.; Hoffmann, G.F.; Carl, M.; Sauer, S.W.; Opladen, T. QDPR homologues in Danio rerio regulate melanin synthesis, early gliogenesis, and glutamine homeostasis. PLoS ONE 2019, 14, e0215162. [CrossRef]

83. Hirata, H.; Carta, E.; Yamanaka, I.; Harvey, R.J.; Kuwada, J.Y. Defective glycinergic synaptic transmission in zebrafish motility mutants. Front. Mol. Neurosci. 2009, 2, 26. [CrossRef]

84. Ogino, K.; Hirata, H. Defects of the Glycinergic Synapse in Zebrafish. Front. Mol. Neurosci. 2016, 9, 50. [CrossRef] [PubMed]

85. Low, S.E.; Ito, D.; Hirata, H. Characterization of the Zebrafish Glycine Receptor Family Reveals Insights Into Glycine Receptor Structure Function and Stoichiometry. Front. Mol. Neurosci. 2018, 11, 286. [CrossRef] [PubMed]

86. Samarut, E.; Chalopin, D.; Riche, R.; Allard, M.; Liao, M.; Drapeau, P. Individual knock out of glycine receptor alpha subunits identifies a specific requirement of glra1 for motor function in zebrafish. PLoS ONE 2019, 14, e0216159. [CrossRef] [PubMed] 
87. Sun, S.N.; Gui, Y.H.; Wang, Y.X.; Qian, L.X.; Jiang, Q.; Liu, D.; Song, H.Y. Effect of dihydrofolate reductase gene knock-down on the expression of heart and neural crest derivatives expressed transcript 2 in zebrafish cardiac development. Chin. Med. J. 2007, 120, 1166-1171. [CrossRef] [PubMed]

88. Kao, T.T.; Wang, K.C.; Chang, W.N.; Lin, C.Y.; Chen, B.H.; Wu, H.L.; Shi, G.Y.; Tsai, J.N.; $\mathrm{Fu}$, T.F. Characterization and comparative studies of zebrafish and human recombinant dihydrofolate reductases-inhibition by folic acid and polyphenols. Drug Metab. Dispos. 2008, 36, 508-516. [CrossRef] [PubMed]

89. Sun, S.; Gui, Y.; Wang, Y.; Qian, L.; Liu, X.; Jiang, Q.; Song, H. Effects of methotrexate on the developments of heart and vessel in zebrafish. Acta Biochim. Biophys. Sin. 2009, 41, 86-96. [CrossRef] [PubMed]

90. Sun, S.N.; Gui, Y.H.; Jiang, Q.; Song, H.Y. [Effects of folic acid on the development of heart of zebrafish]. Zhonghua Er Ke Za Zhi 2010, 48, 905-912.

91. Sun, S.; Gui, Y.; Jiang, Q.; Song, H. Dihydrofolate reductase is required for the development of heart and outflow tract in zebrafish. Acta Biochim. Biophys. Sin. 2011, 43, 957-969. [CrossRef]

92. Lee, M.S.; Bonner, J.R.; Bernard, D.J.; Sanchez, E.L.; Sause, E.T.; Prentice, R.R.; Burgess, S.M.; Brody, L.C. Disruption of the folate pathway in zebrafish causes developmental defects. BMC Dev. Biol. 2012, 12, 12. [CrossRef]

93. Chang, W.N.; Chi, W.Y.; Kao, T.T.; Tsai, J.N.; Liu, W.; Liang, S.S.; Chiu, C.C.; Chen, B.H.; Fu, T.F. The Transgenic Zebrafish Display Fluorescence Reflecting the Expressional Dynamics of Dihydrofolate Reductase. Zebrafish 2017, 14, 223-235. [CrossRef]

94. Thapliyal, C.; Jain, N.; Rashid, N.; Chaudhuri Chattopadhyay, P. Kinetics and thermodynamics of the thermal inactivation and chaperone assisted folding of zebrafish dihydrofolate reductase. Arch Biochem. Biophys. 2018, 637, 21-30. [CrossRef] [PubMed]

95. Matera, C.; Gomila, A.M.J.; Camarero, N.; Libergoli, M.; Soler, C.; Gorostiza, P. Photoswitchable Antimetabolite for Targeted Photoactivated Chemotherapy. J. Am. Chem. Soc. 2018, 140, 15764-15773. [CrossRef]

96. Summar, M.L.; Mew, N.A. Inborn Errors of Metabolism with Hyperammonemia: Urea Cycle Defects and Related Disorders. Pediatr. Clin. North Am. 2018, 65, 231-246. [CrossRef] [PubMed]

97. Feldman, B.; Tuchman, M.; Caldovic, L. A zebrafish model of hyperammonemia. Mol. Genet. Metab. 2014, 113, 142-147. [CrossRef] [PubMed]

98. Zielonka, M.; Breuer, M.; Okun, J.G.; Carl, M.; Hoffmann, G.F.; Kolker, S. Pharmacologic rescue of hyperammonemia-induced toxicity in zebrafish by inhibition of ornithine aminotransferase. PLOS ONE 2018, 13, e0203707. [CrossRef] [PubMed]

99. Zielonka, M.; Probst, J.; Carl, M.; Hoffmann, G.F.; Kolker, S.; Okun, J.G. Bioenergetic dysfunction in a zebrafish model of acute hyperammonemic decompensation. Exp. Neurol. 2019, 314, 91-99. [CrossRef] [PubMed]

100. Probst, J.; Kolker, S.; Okun, J.G.; Kumar, A.; Gursky, E.; Posset, R.; Hoffmann, G.F.; Peravali, R.; Zielonka, M. Chronic hyperammonemia causes a hypoglutamatergic and hyperGABAergic metabolic state associated with neurobehavioral abnormalities in zebrafish larvae. Exp. Neurol. 2020, 331, 113330. [CrossRef]

101. Hicks, J.; Wartchow, E.; Mierau, G. Glycogen storage diseases: A brief review and update on clinical features, genetic abnormalities, pathologic features, and treatment. Ultrastruct. Pathol. 2011, 35, 183-196. [CrossRef]

102. Kanungo, S.; Wells, K.; Tribett, T.; El-Gharbawy, A. Glycogen metabolism and glycogen storage disorders. Ann. Transl. Med. 2018, 6, 474. [CrossRef]

103. Wu, J.; Yang, Y.; Sun, C.; Sun, S.; Li, Q.; Yao, Y.; Fei, F.; Lu, L.; Chang, Z.; Zhang, W.; et al. Disruption of the gaa Gene in Zebrafish Fails to Generate the Phenotype of Classical Pompe Disease. DNA Cell Biol. 2017, 36, 10-17. [CrossRef]

104. Bragato, C.; Carra, S.; Blasevich, F.; Salerno, F.; Brix, A.; Bassi, A.; Beltrame, M.; Cotelli, F.; Maggi, L.; Mantegazza, R.; et al. Glycogen storage in a zebrafish Pompe disease model is reduced by 3-BrPA treatment. Biochim. Biophys. Acta Mol. Basis Dis. 2020, 1866, 165662. [CrossRef]

105. Castillo, J.; Crespo, D.; Capilla, E.; Diaz, M.; Chauvigne, F.; Cerda, J.; Planas, J.V. Evolutionary structural and functional conservation of an ortholog of the GLUT2 glucose transporter gene (SLC2A2) in zebrafish. Am. J. Physiol. Regul Integr. Comp. Physiol. 2009, 297, R1570-R1581. [CrossRef] [PubMed]

106. Marin-Juez, R.; Rovira, M.; Crespo, D.; van der Vaart, M.; Spaink, H.P.; Planas, J.V. GLUT2-mediated glucose uptake and availability are required for embryonic brain development in zebrafish. J. Cereb. Blood Flow Metab. 2015, 35, 74-85. [CrossRef] [PubMed] 
107. Longo, L.; Vanegas, O.C.; Patel, M.; Rosti, V.; Li, H.; Waka, J.; Merghoub, T.; Pandolfi, P.P.; Notaro, R.; Manova, K.; et al. Maternally transmitted severe glucose 6-phosphate dehydrogenase deficiency is an embryonic lethal. EMBO J. 2002, 21, 4229-4239. [CrossRef] [PubMed]

108. Patrinostro, X.; Carter, M.L.; Kramer, A.C.; Lund, T.C. A model of glucose-6-phosphate dehydrogenase deficiency in the zebrafish. Exp. Hematol. 2013,41,697-710. [CrossRef]

109. Hwang, S.; Mruk, K.; Rahighi, S.; Raub, A.G.; Chen, C.-H.; Dorn, L.E.; Horikoshi, N.; Wakatsuki, S.; Chen, J.K.; Mochly-Rosen, D. Correcting glucose-6-phosphate dehydrogenase deficiency with a small-molecule activator. Nat. Commun. 2018, 9, 4045. [CrossRef]

110. Wu, Y.H.; Lee, Y.H.; Shih, H.Y.; Chen, S.H.; Cheng, Y.C.; Tsun-Yee Chiu, D. Glucose-6-phosphate dehydrogenase is indispensable in embryonic development by modulation of epithelial-mesenchymal transition via the NOX/Smad3/miR-200b axis. Cell Death Dis. 2018, 9, 10. [CrossRef] [PubMed]

111. Rubio-Agusti, I.; Carecchio, M.; Bhatia, K.P.; Kojovic, M.; Parees, I.; Chandrashekar, H.S.; Footitt, E.J.; Burke, D.; Edwards, M.J.; Lachmann, R.H.; et al. Movement disorders in adult patients with classical galactosemia. Mov. Disord. 2013, 28, 804-810. [CrossRef]

112. Vanoevelen, J.M.; van Erven, B.; Bierau, J.; Huang, X.; Berry, G.T.; Vos, R.; Coelho, A.I.; Rubio-Gozalbo, M.E. Impaired fertility and motor function in a zebrafish model for classic galactosemia. J. Inherit. Metab. Dis. 2018, 41, 117-127. [CrossRef]

113. Leslie, N.D.; Yager, K.L.; McNamara, P.D.; Segal, S. A mouse model of galactose-1-phosphate uridyl transferase deficiency. Biochem. Mol. Med. 1996, 59, 7-12. [CrossRef]

114. Tang, M.; Siddiqi, A.; Witt, B.; Yuzyuk, T.; Johnson, B.; Fraser, N.; Chen, W.; Rascon, R.; Yin, X.; Goli, H.; et al. Subfertility and growth restriction in a new galactose- 1 phosphate uridylyltransferase (GALT)-deficient mouse model. Eur. J. Hum. Genet. 2014, 22, 1172-1179. [CrossRef] [PubMed]

115. Hughes, J.; Ryan, S.; Lambert, D.; Geoghegan, O.; Clark, A.; Rogers, Y.; Hendroff, U.; Monavari, A.; Twomey, E.; Treacy, E.P. Outcomes of siblings with classical galactosemia. J. Pediatr. 2009, 154, 721-726. [CrossRef] [PubMed]

116. Waisbren, S.E.; Potter, N.L.; Gordon, C.M.; Green, R.C.; Greenstein, P.; Gubbels, C.S.; Rubio-Gozalbo, E.; Schomer, D.; Welt, C.; Anastasoaie, V.; et al. The adult galactosemic phenotype. J. Inherit. Metab. Dis. 2012, 35, 279-286. [CrossRef] [PubMed]

117. Potter, N.L.; Nievergelt, Y.; Shriberg, L.D. Motor and speech disorders in classic galactosemia. JIMD Rep. 2013, 11, 31-41. [CrossRef]

118. Haskovic, M.; Coelho, A.I.; Lindhout, M.; Zijlstra, F.; Veizaj, R.; Vos, R.; Vanoevelen, J.M.; Bierau, J.; Lefeber, D.J.; Rubio-Gozalbo, M.E. Nucleotide sugar profiles throughout development in wildtype and galt knockout zebrafish. J. Inherit. Metab. Dis. 2020. [CrossRef] [PubMed]

119. Jensen, P.J.; Gitlin, J.D.; Carayannopoulos, M.O. GLUT1 deficiency links nutrient availability and apoptosis during embryonic development. J. Biol. Chem. 2006, 281, 13382-13387. [CrossRef] [PubMed]

120. Anderson, J.L.; Carten, J.D.; Farber, S.A. Using fluorescent lipids in live zebrafish larvae: From imaging whole animal physiology to subcellular lipid trafficking. Methods Cell Biol. 2016, 133, 165-178. [CrossRef]

121. Fang, L.; Liu, C.; Miller, Y.I. Zebrafish models of dyslipidemia: Relevance to atherosclerosis and angiogenesis. Transl. Res. 2014, 163, 99-108. [CrossRef]

122. Schlegel, A. Zebrafish Models for Dyslipidemia and Atherosclerosis Research. Front. Endocrinol. 2016, 7, 159. [CrossRef]

123. Ishibashi, S.; Goldstein, J.L.; Brown, M.S.; Herz, J.; Burns, D.K. Massive xanthomatosis and atherosclerosis in cholesterol-fed low density lipoprotein receptor-negative mice. J. Clin. Investig. 1994, 93, 1885-1893. [CrossRef]

124. O'Hare, E.A.; Wang, X.; Montasser, M.E.; Chang, Y.P.; Mitchell, B.D.; Zaghloul, N.A. Disruption of ldlr causes increased LDL-c and vascular lipid accumulation in a zebrafish model of hypercholesterolemia. J. Lipid Res. 2014, 55, 2242-2253. [CrossRef] [PubMed]

125. Liu, C.; Kim, Y.S.; Kim, J.; Pattison, J.; Kamaid, A.; Miller, Y.I. Modeling hypercholesterolemia and vascular lipid accumulation in LDL receptor mutant zebrafish. J. Lipid Res. 2018, 59, 391-399. [CrossRef] [PubMed]

126. Luo, H.; Li, Q.Q.; Wu, N.; Shen, Y.G.; Liao, W.T.; Yang, Y.; Dong, E.; Zhang, G.M.; Liu, B.R.; Yue, X.Z.; et al. Chronological in vivo imaging reveals endothelial inflammation prior to neutrophils accumulation and lipid deposition in HCD-fed zebrafish. Atherosclerosis 2019, 290, 125-135. [CrossRef] [PubMed] 
127. Han, B.; Kou, S.; He, K.; Han, Y.; Wang, Y.; Huang, T.; Zhou, X.; Xiao, Y.; Li, X.; Ye, X. Anti-hypercholesterolemic Effect of Berbamine Isolated from Rhizoma Coptidis in Hypercholesterolemic Zebrafish Induced by High-Cholesterol Diet. Iran J. Pharm. Res. 2018, 17, 292-306. [PubMed]

128. Li, F.; Wu, Z.; Sui, X. Biotransformation of ginsenoside Rb1 with wild Cordyceps sinensis and Ascomycota sp. and its antihyperlipidemic effects on the diet-induced cholesterol of zebrafish. J. Food Biochem. 2020, 44, e13192. [CrossRef]

129. Hoppstadter, J.; Valbuena Perez, J.V.; Linnenberger, R.; Dahlem, C.; Legroux, T.M.; Hecksteden, A.; Tse, W.K.F.; Flamini, S.; Andreas, A.; Herrmann, J.; et al. The glucocorticoid-induced leucine zipper mediates statin-induced muscle damage. FASEB J. 2020, 34, 4684-4701. [CrossRef]

130. Liu, C.; Gates, K.P.; Fang, L.; Amar, M.J.; Schneider, D.A.; Geng, H.; Huang, W.; Kim, J.; Pattison, J.; Zhang, J.; et al. Apoc2 loss-of-function zebrafish mutant as a genetic model of hyperlipidemia. Dis. Model. Mech. 2015, 8, 989-998. [CrossRef]

131. Matthijs, G.; Schollen, E.; Pardon, E.; Veiga-Da-Cunha, M.; Jaeken, J.; Cassiman, J.J.; Van Schaftingen, E. Mutations in PMM2, a phosphomannomutase gene on chromosome 16p13, in carbohydrate-deficient glycoprotein type I syndrome (Jaeken syndrome). Nat. Genet. 1997, 16, 88-92. [CrossRef]

132. Iyer, S.; Sam, F.S.; DiPrimio, N.; Preston, G.; Verheijen, J.; Murthy, K.; Parton, Z.; Tsang, H.; Lao, J.; Morava, E.; et al. Repurposing the aldose reductase inhibitor and diabetic neuropathy drug epalrestat for the congenital disorder of glycosylation PMM2-CDG. Dis. Models Mech. 2019, 12. [CrossRef]

133. Himmelreich, N.; Kaufmann, L.T.; Steinbeisser, H.; Korner, C.; Thiel, C. Lack of phosphomannomutase 2 affects Xenopus laevis morphogenesis and the non-canonical Wnt5a/Ror2 signalling. J. Inherit Metab. Dis. 2015, 38, 1137-1146. [CrossRef]

134. Lao, J.P.; DiPrimio, N.; Prangley, M.; Sam, F.S.; Mast, J.D.; Perlstein, E.O. Yeast Models of Phosphomannomutase 2 Deficiency, a Congenital Disorder of Glycosylation. G3 Genes Genomes Genet. 2019, 9, 413-423. [CrossRef]

135. Cline, A.; Gao, N.; Flanagan-Steet, H.; Sharma, V.; Rosa, S.; Sonon, R.; Azadi, P.; Sadler, K.C.; Freeze, H.H.; Lehrman, M.A.; et al. A zebrafish model of PMM2-CDG reveals altered neurogenesis and a substrate-accumulation mechanism for N-linked glycosylation deficiency. Mol. Biol. Cell 2012, 23, 4175-4187. [CrossRef] [PubMed]

136. Mukaigasa, K.; Tsujita, T.; Nguyen, V.T.; Li, L.; Yagi, H.; Fuse, Y.; Nakajima-Takagi, Y.; Kato, K.; Yamamoto, M.; Kobayashi, M. Nrf2 activation attenuates genetic endoplasmic reticulum stress induced by a mutation in the phosphomannomutase 2 gene in zebrafish. Proc. Natl. Acad. Sci. USA 2018, 115, 2758-2763. [CrossRef] [PubMed]

137. Chu, J.; Mir, A.; Gao, N.; Rosa, S.; Monson, C.; Sharma, V.; Steet, R.; Freeze, H.H.; Lehrman, M.A.; Sadler, K.C. A zebrafish model of congenital disorders of glycosylation with phosphomannose isomerase deficiency reveals an early opportunity for corrective mannose supplementation. Dis. Models Mech. 2013, 6, 95-105. [CrossRef] [PubMed]

138. DeRossi, C.; Bode, L.; Eklund, E.A.; Zhang, F.; Davis, J.A.; Westphal, V.; Wang, L.; Borowsky, A.D.; Freeze, H.H. Ablation of mouse phosphomannose isomerase (Mpi) causes mannose 6-phosphate accumulation, toxicity, and embryonic lethality. J. Biol. Chem. 2006, 281, 5916-5927. [CrossRef] [PubMed]

139. Neitzel, L.R.; Spencer, Z.T.; Nayak, A.; Cselenyi, C.S.; Benchabane, H.; Youngblood, C.Q.; Zouaoui, A.; Ng, V.; Stephens, L.; Hann, T.; et al. Developmental regulation of Wnt signaling by Nagk and the UDP-GlcNAc salvage pathway. Mech. Dev. 2019, 156, 20-31. [CrossRef] [PubMed]

140. Pacheco-Cuellar, G.; Gauthier, J.; Desilets, V.; Lachance, C.; Lemire-Girard, M.; Rypens, F.; Le Deist, F.; Decaluwe, H.; Duval, M.; Bouron-Dal Soglio, D.; et al. A Novel PGM3 Mutation Is Associated With a Severe Phenotype of Bone Marrow Failure, Severe Combined Immunodeficiency, Skeletal Dysplasia, and Congenital Malformations. J. Bone Min. Res. 2017, 32, 1853-1859. [CrossRef]

141. Stray-Pedersen, A.; Backe, P.H.; Sorte, H.S.; Morkrid, L.; Chokshi, N.Y.; Erichsen, H.C.; Gambin, T.; Elgstoen, K.B.; Bjoras, M.; Wlodarski, M.W.; et al. PGM3 mutations cause a congenital disorder of glycosylation with severe immunodeficiency and skeletal dysplasia. Am. J. Hum. Genet. 2014, 95, 96-107. [CrossRef]

142. Bammens, R.; Mehta, N.; Race, V.; Foulquier, F.; Jaeken, J.; Tiemeyer, M.; Steet, R.; Matthijs, G.; Flanagan-Steet, H. Abnormal cartilage development and altered N-glycosylation in Tmem165-deficient zebrafish mirrors the phenotypes associated with TMEM165-CDG. Glycobiology 2015, 25, 669-682. [CrossRef] 
143. Zeevaert, R.; de Zegher, F.; Sturiale, L.; Garozzo, D.; Smet, M.; Moens, M.; Matthijs, G.; Jaeken, J. Bone Dysplasia as a Key Feature in Three Patients with a Novel Congenital Disorder of Glycosylation (CDG) Type II Due to a Deep Intronic Splice Mutation in TMEM165. JIMD Rep. 2013, 8, 145-152. [CrossRef]

144. Sadler, K.C.; Amsterdam, A.; Soroka, C.; Boyer, J.; Hopkins, N. A genetic screen in zebrafish identifies the mutants vps18, nf2 and foie gras as models of liver disease. Development 2005, 132, 3561-3572. [CrossRef] [PubMed]

145. Cinaroglu, A.; Gao, C.; Imrie, D.; Sadler, K.C. Activating transcription factor 6 plays protective and pathological roles in steatosis due to endoplasmic reticulum stress in zebrafish. Hepatology 2011, 54, 495-508. [CrossRef] [PubMed]

146. Liang, W.C.; Zhu, W.; Mitsuhashi, S.; Noguchi, S.; Sacher, M.; Ogawa, M.; Shih, H.H.; Jong, Y.J.; Nishino, I. Congenital muscular dystrophy with fatty liver and infantile-onset cataract caused by TRAPPC11 mutations: Broadening of the phenotype. Skelet Muscle 2015, 5, 29. [CrossRef] [PubMed]

147. DeRossi, C.; Vacaru, A.; Rafiq, R.; Cinaroglu, A.; Imrie, D.; Nayar, S.; Baryshnikova, A.; Milev, M.P.; Stanga, D.; Kadakia, D.; et al. trappc11 is required for protein glycosylation in zebrafish and humans. Mol. Biol. Cell 2016, 27, 1220-1234. [CrossRef] [PubMed]

148. Matalonga, L.; Bravo, M.; Serra-Peinado, C.; Garcia-Pelegri, E.; Ugarteburu, O.; Vidal, S.; Llambrich, M.; Quintana, E.; Fuster-Jorge, P.; Gonzalez-Bravo, M.N.; et al. Mutations in TRAPPC11 are associated with a congenital disorder of glycosylation. Hum. Mutat. 2017, 38, 148-151. [CrossRef] [PubMed]

149. Jaeken, J.; Peanne, R. What is new in CDG? J. Inherit Metab. Dis. 2017, 40, 569-586. [CrossRef]

150. Taylor, M.R.; Hurley, J.B.; Van Epps, H.A.; Brockerhoff, S.E. A zebrafish model for pyruvate dehydrogenase deficiency: Rescue of neurological dysfunction and embryonic lethality using a ketogenic diet. Proc. Natl. Acad. Sci. USA 2004, 101, 4584-4589. [CrossRef]

151. Brockerhoff, S.E.; Hurley, J.B.; Janssen-Bienhold, U.; Neuhauss, S.C.; Driever, W.; Dowling, J.E. A behavioral screen for isolating zebrafish mutants with visual system defects. Proc. Natl. Acad. Sci. USA 1995, 92, 10545-10549. [CrossRef] [PubMed]

152. Wijburg, F.A.; Barth, P.G.; Bindoff, L.A.; Birch-Machin, M.A.; van der Blij, J.F.; Ruitenbeek, W.; Turnbull, D.M.; Schutgens, R.B. Leigh syndrome associated with a deficiency of the pyruvate dehydrogenase complex: Results of treatment with a ketogenic diet. Neuropediatrics 1992, 23, 147-152. [CrossRef]

153. Maurer, C.M.; Schonthaler, H.B.; Mueller, K.P.; Neuhauss, S.C. Distinct retinal deficits in a zebrafish pyruvate dehydrogenase-deficient mutant. J. Neurosci. 2010, 30, 11962-11972. [CrossRef]

154. Ferriero, R.; Manco, G.; Lamantea, E.; Nusco, E.; Ferrante, M.I.; Sordino, P.; Stacpoole, P.W.; Lee, B.; Zeviani, M.; Brunetti-Pierri, N. Phenylbutyrate therapy for pyruvate dehydrogenase complex deficiency and lactic acidosis. Sci. Transl. Med. 2013, 5, 175ra131. [CrossRef] [PubMed]

155. Platt, F.M.; d'Azzo, A.; Davidson, B.L.; Neufeld, E.F.; Tifft, C.J. Lysosomal storage diseases. Nat. Rev. Dis. Primers 2018, 4, 27. [CrossRef] [PubMed]

156. Ferreira, C.R.; Gahl, W.A. Lysosomal storage diseases. Transl. Sci. Rare Dis. 2017, 2, 1-71. [CrossRef] [PubMed]

157. Meikle, P.J.; Hopwood, J.J.; Clague, A.E.; Carey, W.F. Prevalence of lysosomal storage disorders. JAMA 1999, 281, 249-254. [CrossRef] [PubMed]

158. Chen, Z.; Luciani, A.; Mateos, J.M.; Barmettler, G.; Giles, R.H.; Neuhauss, S.C.F.; Devuyst, O. Transgenic zebrafish modeling low-molecular-weight proteinuria and lysosomal storage diseases. Kidney Int. 2020, 97, 1150-1163. [CrossRef] [PubMed]

159. Zhang, T.; Peterson, R.T. Modeling Lysosomal Storage Diseases in the Zebrafish. Front. Mol. Biosci. 2020, 7, 82. [CrossRef]

160. Grabowski, G.A. Gaucher disease and other storage disorders. Hematol. Am. Soc. Hematol. Educ. Program. 2012, 2012, 13-18. [CrossRef]

161. Baris, H.N.; Cohen, I.J.; Mistry, P.K. Gaucher disease: The metabolic defect, pathophysiology, phenotypes and natural history. Pediatr. Endocrinol. Rev. 2014, 12, 72-81.

162. Rosenbloom, B.; Balwani, M.; Bronstein, J.M.; Kolodny, E.; Sathe, S.; Gwosdow, A.R.; Taylor, J.S.; Cole, J.A.; Zimran, A.; Weinreb, N.J. The incidence of Parkinsonism in patients with type 1 Gaucher disease: Data from the ICGG Gaucher Registry. Blood. Cells Mol. Dis. 2011, 46, 95-102. [CrossRef]

163. Keatinge, M.; Bui, H.; Menke, A.; Chen, Y.C.; Sokol, A.M.; Bai, Q.; Ellett, F.; Da Costa, M.; Burke, D.; Gegg, M.; et al. Glucocerebrosidase 1 deficient Danio rerio mirror key pathological aspects of human Gaucher disease 
and provide evidence of early microglial activation preceding alpha-synuclein-independent neuronal cell death. Hum. Mol. Genet. 2015, 24, 6640-6652. [CrossRef]

164. Toni, M.; Cioni, C. Fish Synucleins: An Update. Mar. Drugs 2015, 13, 6665-6686. [CrossRef] [PubMed]

165. Watson, L.; Keatinge, M.; Gegg, M.; Bai, Q.; Sandulescu, M.C.; Vardi, A.; Futerman, A.H.; Schapira, A.H.V.; Burton, E.A.; Bandmann, O. Ablation of the pro-inflammatory master regulator miR-155 does not mitigate neuroinflammation or neurodegeneration in a vertebrate model of Gaucher's disease. Neurobiol. Dis. 2019, 127, 563-569. [CrossRef] [PubMed]

166. Zancan, I.; Bellesso, S.; Costa, R.; Salvalaio, M.; Stroppiano, M.; Hammond, C.; Argenton, F.; Filocamo, M.; Moro, E. Glucocerebrosidase deficiency in zebrafish affects primary bone ossification through increased oxidative stress and reduced Wnt/beta-catenin signaling. Hum. Mol. Genet. 2015, 24, 1280-1294. [CrossRef] [PubMed]

167. Artola, M.; Kuo, C.L.; Lelieveld, L.T.; Rowland, R.J.; van der Marel, G.A.; Codee, J.D.C.; Boot, R.G.; Davies, G.J.; Aerts, J.; Overkleeft, H.S. Functionalized Cyclophellitols Are Selective Glucocerebrosidase Inhibitors and Induce a Bona Fide Neuropathic Gaucher Model in Zebrafish. J. Am. Chem. Soc. 2019, 141, 4214-4218. [CrossRef] [PubMed]

168. Lelieveld, L.T.; Mirzaian, M.; Kuo, C.L.; Artola, M.; Ferraz, M.J.; Peter, R.E.A.; Akiyama, H.; Greimel, P.; van den Berg, R.; Overkleeft, H.S.; et al. Role of beta-glucosidase 2 in aberrant glycosphingolipid metabolism: Model of glucocerebrosidase deficiency in zebrafish. J. Lipid Res. 2019, 60, 1851-1867. [CrossRef] [PubMed]

169. Carstea, E.D.; Morris, J.A.; Coleman, K.G.; Loftus, S.K.; Zhang, D.; Cummings, C.; Gu, J.; Rosenfeld, M.A.; Pavan, W.J.; Krizman, D.B.; et al. Niemann-Pick C1 disease gene: Homology to mediators of cholesterol homeostasis. Science 1997, 277, 228-231. [CrossRef] [PubMed]

170. Vanier, M.T. Niemann-Pick disease type C. Orphanet J. Rare Dis. 2010, 5, 16. [CrossRef] [PubMed]

171. Vanier, M.T.; Millat, G. Structure and function of the NPC2 protein. Biochim. Biophys. Acta 2004, 1685, 14-21. [CrossRef] [PubMed]

172. Kelly, D.A.; Portmann, B.; Mowat, A.P.; Sherlock, S.; Lake, B.D. Niemann-Pick disease type C: Diagnosis and outcome in children, with particular reference to liver disease. J. Pediatr. 1993, 123, 242-247. [CrossRef]

173. Patterson, M.C.; Mengel, E.; Wijburg, F.A.; Muller, A.; Schwierin, B.; Drevon, H.; Vanier, M.T.; Pineda, M. Disease and patient characteristics in NP-C patients: Findings from an international disease registry. Orphanet J. Rare Dis 2013, 8, 12. [CrossRef]

174. Mengel, E.; Pineda, M.; Hendriksz, C.J.; Walterfang, M.; Torres, J.V.; Kolb, S.A. Differences in Niemann-Pick disease Type C symptomatology observed in patients of different ages. Mol. Genet. Metab. 2017, 120, 180-189. [CrossRef] [PubMed]

175. Tseng, W.C.; Loeb, H.E.; Pei, W.; Tsai-Morris, C.H.; Xu, L.; Cluzeau, C.V.; Wassif, C.A.; Feldman, B.; Burgess, S.M.; Pavan, W.J.; et al. Modeling Niemann-Pick disease type C1 in zebrafish: A robust platform for in vivo screening of candidate therapeutic compounds. Dis. Model. Mech. 2018, 11. [CrossRef] [PubMed]

176. Lin, Y.; Cai, X.; Wang, G.; Ouyang, G.; Cao, H. Model construction of Niemann-Pick type C disease in zebrafish. Biol. Chem. 2018, 399, 903-910. [CrossRef] [PubMed]

177. Schwend, T.; Loucks, E.J.; Snyder, D.; Ahlgren, S.C. Requirement of Npc1 and availability of cholesterol for early embryonic cell movements in zebrafish. J. Lipid Res. 2011, 52, 1328-1344. [CrossRef] [PubMed]

178. Louwette, S.; Regal, L.; Wittevrongel, C.; Thys, C.; Vandeweeghde, G.; Decuyper, E.; Leemans, P.; De Vos, R.; Van Geet, C.; Jaeken, J.; et al. NPC1 defect results in abnormal platelet formation and function: Studies in Niemann-Pick disease type C1 patients and zebrafish. Hum. Mol. Genet. 2013, 22, 61-73. [CrossRef] [PubMed]

179. Walkley, S.U.; Suzuki, K. Consequences of NPC1 and NPC2 loss of function in mammalian neurons. Biochim. Biophys. Acta 2004, 1685, 48-62. [CrossRef]

180. Liu, B.; Turley, S.D.; Burns, D.K.; Miller, A.M.; Repa, J.J.; Dietschy, J.M. Reversal of defective lysosomal transport in NPC disease ameliorates liver dysfunction and neurodegeneration in the npc1-/- mouse. Proc. Natl. Acad. Sci. USA 2009, 106, 2377-2382. [CrossRef]

181. Ory, D.S.; Ottinger, E.A.; Farhat, N.Y.; King, K.A.; Jiang, X.; Weissfeld, L.; Berry-Kravis, E.; Davidson, C.D.; Bianconi, S.; Keener, L.A.; et al. Intrathecal 2-hydroxypropyl-beta-cyclodextrin decreases neurological disease progression in Niemann-Pick disease, type C1: A non-randomised, open-label, phase 1-2 trial. Lancet 2017, 390, 1758-1768. [CrossRef] 
182. Ehlert, K.; Frosch, M.; Fehse, N.; Zander, A.; Roth, J.; Vormoor, J. Farber disease: Clinical presentation, pathogenesis and a new approach to treatment. Pediatr. Rheumatol. Online J. 2007, 5, 15. [CrossRef]

183. Yu, F.P.S.; Amintas, S.; Levade, T.; Medin, J.A. Acid ceramidase deficiency: Farber disease and SMA-PME. Orphanet J. Rare Dis. 2018, 13, 121. [CrossRef]

184. Zhou, J.; Tawk, M.; Tiziano, F.D.; Veillet, J.; Bayes, M.; Nolent, F.; Garcia, V.; Servidei, S.; Bertini, E.; Castro-Giner, F.; et al. Spinal muscular atrophy associated with progressive myoclonic epilepsy is caused by mutations in ASAH1. Am. J. Hum. Genet. 2012, 91, 5-14. [CrossRef] [PubMed]

185. Zhang, T.; Trauger, S.A.; Vidoudez, C.; Doane, K.P.; Pluimer, B.R.; Peterson, R.T. Parallel Reaction Monitoring reveals structure-specific ceramide alterations in the zebrafish. Sci. Rep. 2019, 9, 19939. [CrossRef] [PubMed]

186. Neufeld, E.F.; Muenzer, J. The mucopolysaccharidosis. In The Metabolic and Molecular Bases of Inherited Disease; Scriver, C.R., Beaudet, A.L., Sly, W.S., Valle, D., Eds.; McGraw-Hill: New York, NY, USA, 2001; pp. 3421-3452.

187. Giugliani, R.; Federhen, A.; Rojas, M.V.; Vieira, T.; Artigalas, O.; Pinto, L.L.; Azevedo, A.C.; Acosta, A.; Bonfim, C.; Lourenco, C.M.; et al. Mucopolysaccharidosis I, II, and VI: Brief review and guidelines for treatment. Genet. Mol. Biol. 2010, 33, 589-604. [CrossRef] [PubMed]

188. Fecarotta, S.; Gasperini, S.; Parenti, G. New treatments for the mucopolysaccharidoses: From pathophysiology to therapy. Ital. J. Pediatr. 2018, 44, 124. [CrossRef] [PubMed]

189. Moro, E.; Tomanin, R.; Friso, A.; Modena, N.; Tiso, N.; Scarpa, M.; Argenton, F. A novel functional role of iduronate-2-sulfatase in zebrafish early development. Matrix Biol. 2010, 29, 43-50. [CrossRef] [PubMed]

190. Costa, R.; Urbani, A.; Salvalaio, M.; Bellesso, S.; Cieri, D.; Zancan, I.; Filocamo, M.; Bonaldo, P.; Szabo, I.; Tomanin, R.; et al. Perturbations in cell signaling elicit early cardiac defects in mucopolysaccharidosis type II. Hum. Mol. Genet. 2017, 26, 1643-1655. [CrossRef]

191. Bellesso, S.; Salvalaio, M.; Lualdi, S.; Tognon, E.; Costa, R.; Braghetta, P.; Giraudo, C.; Stramare, R.; Rigon, L.; Filocamo, M.; et al. FGF signaling deregulation is associated with early developmental skeletal defects in animal models for mucopolysaccharidosis type II (MPSII). Hum. Mol. Genet. 2018, 27, 2407. [CrossRef]

192. Konno, M.; Asai, A.; Kitagawa, T.; Yabumoto, M.; Ofusa, K.; Arai, T.; Hirotsu, T.; Doki, Y.; Eguchi, H.; Ishii, H. State-of-the-Art Technology of Model Organisms for Current Human Medicine. Diagnostics 2020, 10, 392. [CrossRef]

193. Patterson, V.L.; Burdine, R.D. Swimming toward solutions: Using fish and frogs as models for understanding RASopathies. Birth Defects Res. 2020, 112, 749-765. [CrossRef]

194. Xiao, J.; Glasgow, E.; Agarwal, S. Zebrafish Xenografts for Drug Discovery and Personalized Medicine. Trends Cancer 2020, 6, 569-579. [CrossRef]

195. Shrestha, R.; Lieberth, J.; Tillman, S.; Natalizio, J.; Bloomekatz, J. Using Zebrafish to Analyze the Genetic and Environmental Etiologies of Congenital Heart Defects. Adv. Exp. Med. Biol. 2020, 1236, 189-223. [CrossRef] [PubMed]

196. Patten, S.A.; Armstrong, G.A.; Lissouba, A.; Kabashi, E.; Parker, J.A.; Drapeau, P. Fishing for causes and cures of motor neuron disorders. Dis. Model. Mech. 2014, 7, 799-809. [CrossRef] [PubMed]

197. Unal, I.; Emekli-Alturfan, E. Fishing for Parkinson's Disease: A review of the literature. J. Clin. Neurosci. 2019, 62, 1-6. [CrossRef] [PubMed]

(C) 2020 by the authors. Licensee MDPI, Basel, Switzerland. This article is an open access article distributed under the terms and conditions of the Creative Commons Attribution (CC BY) license (http://creativecommons.org/licenses/by/4.0/). 